\title{
Original paper \\ Felsic diapirism beneath the high-grade terrains in the eastern Bohemian Massif - refraction tomography evidence
}

\author{
Miroslav NOVOTNÝ
}

On retire from Institute of Geophysics, Academy of Sciences of the Czech Republic, Bočni II/1401, 14131 Prague 4, Czech Republic; mirnovotny@seznam.cz

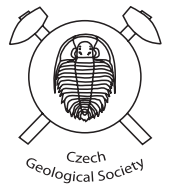

Unlike standard ray-based tomographies, the Depth-Recursive Tomography on Grid (DRTG) method assesses the travel-time fit at each model grid node using a regular network of refraction rays. This concept allows estimating the lateral resolution achieved in the velocity image that regards the chosen confidence levels and the strength of velocity anomalies. Recently, The DRTG has been applied to the S01 and CEL09 refraction profiles imaging major crustal structures of the Bohemian Massif in enhanced resolution. Now, similar enhanced velocity models are derived along the S04, S02 and S03 profiles mapping the Sudetic and Moldanubian regions. The S02 and S03 and the transverse CEL09 and S04 velocity sections particularly imaged the subsurface of the Moldanubian high-grade belts to the $15-20 \mathrm{~km}$ depth. Their common interpretation revealed the signatures of exhumation processes from upper-mantle depths assumed in this region. Particularly, the S02 and S03 sections map large volumes of high-grade metamorphic rocks forming low-velocity (LV) diapirs that are surrounded by 7000-6400 m/s high-velocity (HV) elevations. The S03 section images the coupled HV-LV-HV anomalies beneath the high-grade complexes of the Orlica-Śnieżnik Dome (OSD) and the Góry-Sowie Unit (GSU). The central gradient-free LV $(5800-6000 \mathrm{~m} / \mathrm{s})$ cores of these triplets apparently correspond to the OSD or GSU felsic granulites/gneisses that ascended to supra-crustal levels.

The Bouguer anomaly map suggests that the S02 and S03 profiles intersect the felsic sheets formed along the transverse Sudetic faults. Along the western belt of Moldanubian high-grade rocks, the S02 section revealed an extensive HV body shallowly emplaced beneath the high-grade Gföhl and Ostrong assemblages. Three mid-crustal HV elevations, correlating with local magnetic anomalies, obviously represent the deep sources of this HV mafic body and indicate its autochthonous nature. Finally, the DRTG also detected a shallowly emplaced HV layer beneath the Saxonian Granulite Massif at the S04 section. The mid-crustal HV-LV-HV diapiric triplets and shallowly emplaced HV bodies are likely typical of the high-grade terrains. The observed patterns resulted from contemporaneous intrusion of mafic and, more viscous, felsic magmas during continental collision. The inferred structural features of subduction-exhumation processes are suggested to further constrain their thermo-mechanic modeling.

Keywords: high-grade terrains, eastern Bohemian Massif, depth-recursive refraction tomography, SUDETES 2003 refraction profiles, coupled mafic and felsic diapiric ascents, sub-horizontal mafic bodies

Received: 25 June 2017; accepted: 5 October 2018; handling editor: A. Guy

The online version of this article (doi: 10.3190/jgeosci. 270) contains supplementary electronic material.

\section{Introduction}

The last of three international refraction experiments CELEBRATION 2000, ALP 2002 and SUDETES 2003 (Guterch et al. 2003a) was aimed to provide seismic data to investigate the Variscan structures of the Bohemian Massif and its surroundings (Grad et al. 2003). The region of interest in this paper, the high-grade terrains in the eastern Bohemian Massif, is intersected by four profiles, CEL09, S04, S02 and S03. The previously developed 2-D models along these profiles involved the Earth's crust and upper mantle. Up to now, no special efforts have been devoted to the upper crust and to correlate the results with known geological features. The aim of this study is to change this situation and obtain reliable tomography results allowing geological interpretation.
The previous tomography studies derived the structural models fitting the wide-angle seismic data, i.e., the arrivals of both the refraction and reflection waves recorded along profiles. However, the uncertainties in determination of the wave arrivals inherently differ: the refraction waves coming first could be determined $5-10 \times$ more accurately than the waves arriving later because of their mutual interferences. Therefore, due to the substantially lower input travel-times errors, the inverse methods based only on the refraction data can achieve more reliable and higher resolution velocity models. Moreover, the prevailingly used approach is so-called interactive modeling or trial-and-error method that hardly involves more than several hundreds of model parameters, mostly selectively chosen and tested. On the other hand, the inverse methods can uniformly restore all model parameters in many iterations. Such an inverse method will be applied here, 


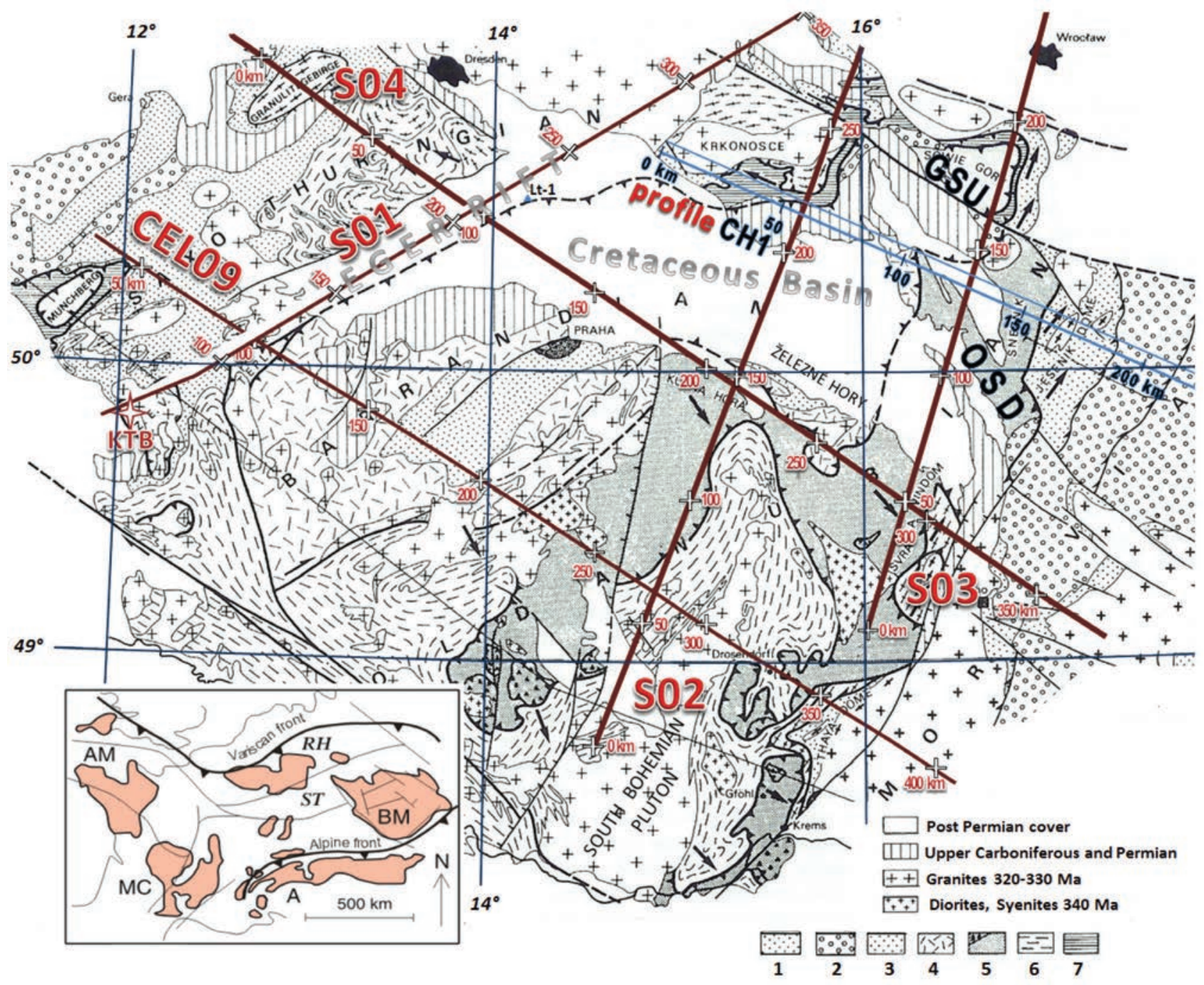

Fig. 1 The seismic SUDETES 2003 (S01-S04), CELEBRATION 2000 (CEL09) and gravity modeling (CH1) profiles with the $50 \mathrm{~km}$ distance ticks on the tectonic sketch of the Bohemian Massif (BM) adapted after Matte (1990). Saxothuringian: 1 - Cambrian to Devonian metasediments; 2 - Lower Carboniferous; Teplá-Barrandian Unit (TBU): 3 - Cambrian to Devonian sediments; 4 - Late Proterozoic pelitic and volcanic series; Moldanubian: 5 - High-grade gneisses and amphibolites with HP granulites, eclogites and garnet peridotites, 6 - Upper Proterozoic to Lower Paleozoic metasediments, 7 - Lower epizonal unit with mafic and ultramafic rocks; OSD - Orlica-Śnieżnik Dome, GSU - Gory Sowie Unit. Inset shows the BM position within the European Variscides: AM - Armorican Massif; MC - Massif Central; A - Alps; RH, ST - Rhenohercynian and Saxothuringian zones (after Pitra et al. 1999).

using grid models that are parametrized by the values of searched P-wave velocity distribution at the model nodes. Since the method is iterative, it allows to obtain a verified velocity image close to the investigated medium.

\section{Overview of previous studies}

\subsection{Geological setting}

Within the European Variscides, the Bohemian Massif represents their easternmost exposure. The central part of the Bohemian Massif includes the Moldanubian Zone s. S., the orogenic root with high-grade units developed during the Variscan collision (Fig. 1). Schulmann et al. 2009, 2014) described the Variscan Orogeny as Andeantype convergence, i.e., the upper plate orogeny developed above a long-lasting Devonian-Carboniferous subduction system. Žák et al. (2014) summarized a concise platekinematic history of the Bohemian Massif assemblage as constrained by the Variscan plutonism.

The Variscan Orogeny started by the its Devonian-Early Carboniferous subduction and closure of Saxothuringian (SXT) Ocean. The SXT slab proceeded toward SE beneath the Teplá-Barrandian Unit (TBU) and Moldanubian (MLD) Zone (Matte et al. 1990; Edel 
and Weber 1995; Franke and Żelaźniewicz 2000). During the Late Devonian-Early Carboniferous, the Central Bohemian Plutonic Complex (CBPC) developed at the TBU-MLD contact as a subduction-related magmatic arc (Janoušek et al. 2000, Žák et al. 2005, 2011). Following the collision, the Brunia promontory indented the deeply subducted Saxothuringian crust and caused the emergence of deeply buried rocks along the boundaries of the Moldanubian with the Moravo-Silesian and Teplá-Barrandian units (Finger et al. 2007; Schulmann et al. 2014). The high-grade terrains, which developed in the MLD, form two NE-SW trending belts. They were one of the targets of the refraction survey performed in the Central Europe (Guterch et al. 2003a). In particular, the S02 and S03 profiles, projected along these high-grade belts, provided seismic data to explore their crustal architecture on a regional scale (Fig. 2).

\subsection{Previous seismic investigations}

The S02, S03, S04 and CEL09 refraction profiles of the SUDETES 2003 and CELEBRATION 2000 experiments provided wide-angle data for regional studies of the Bohemian Massif and West Sudetes (Grad et al. 2003; Guterch et al. 2003b). Figures 1-3 illustrate the profile network on the geological background. Several studies, based on the refraction data, have inferred the structural models of the crust and uppermost mantle along these profiles.

Hrubcová et al. $(2005,2010)$ used wide-angle seismic data for the CEL09 and S04 models involving the entire crust and upper mantle of the BM. The models were obtained by raytracing refinements of initial

Fig. 2 The fault systems and terrane boundaries in the southern Moldanubian sector after Finger et al. (2007). The engaged seismic lines are depicted with the $50 \mathrm{~km}$ ticks. The SW-NE trending fault zones (bold): the Blanice-Kaplice-Rödl, Přibyslav-Vitis and Boskovice-Diendorf fault zones. Added (dashed): the Jáchymov Fault (JF) and marginal Fault of the Třebon Basin (FTB). KHCC - Kutná Hora Crystalline Unit. velocity distributions and fit the observed refraction and reflection travel times. These studies, using the interactive ray-tracing and, partially, seismic amplitude modeling, provided basic information about the crustal architecture and crust-mantle transition.

More sophisticated inverse methods were used by Majdanski et al. (2006) for the S02, S03 seismic data. Two different inverse method applied, commonly revealed the crustal-scale velocity heterogeneities in the $\mathrm{S} 02$ and $\mathrm{S} 03$ sections. However, these extensive velocity anomalies did not appear in their final structural models. Later, including also the data from the CELEBRATION 2000 and POLONAISE'97 seismic experiments, Majdanski et al. (2007) elaborated a 3-D model of the northern part of the Bohemian Massif. As reported, the inferred 3-D model showed good correlation with surface geology down to $2 \mathrm{~km}$ depth. The authors found a strong dependence of the obtained models on the computational schemes used

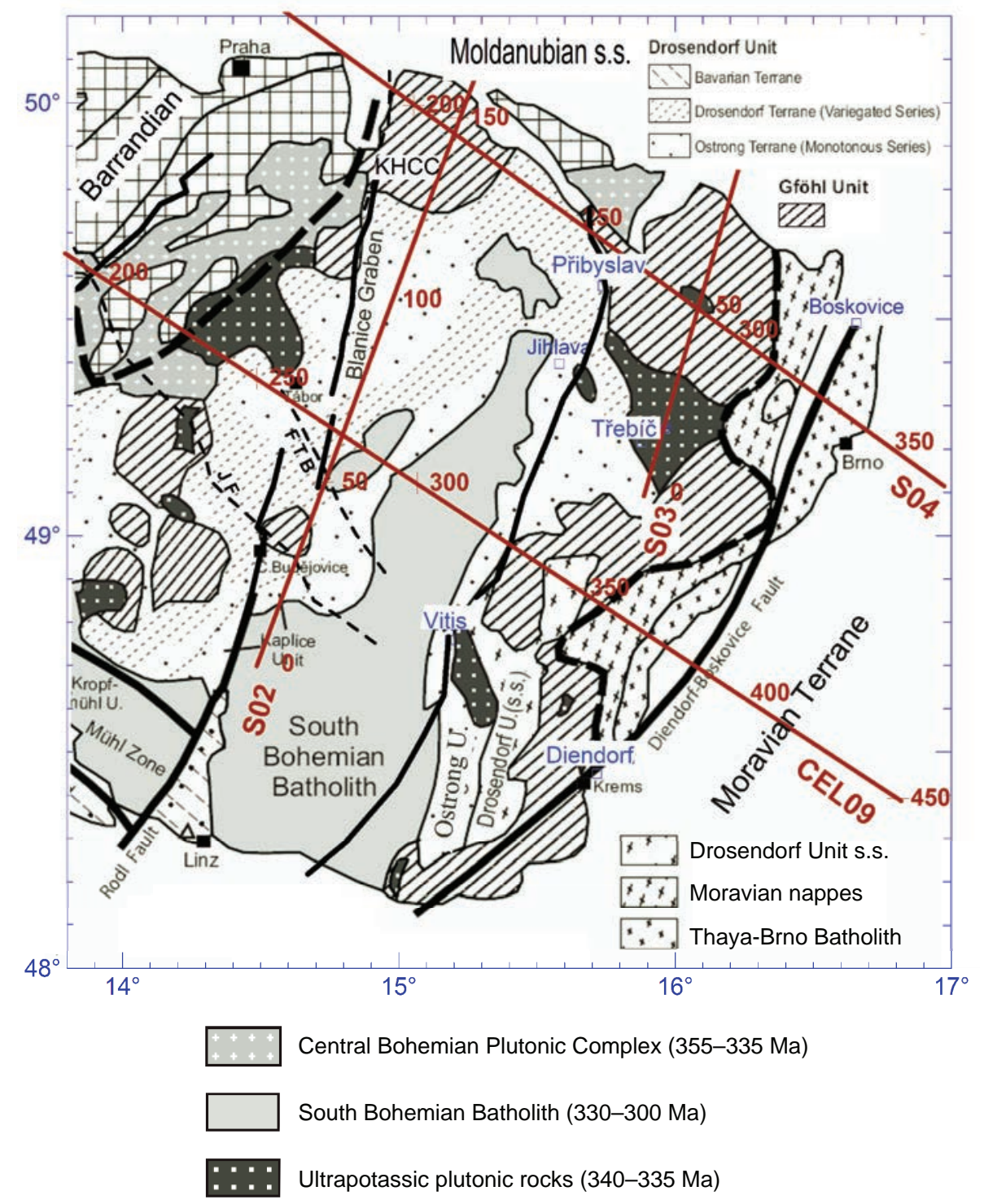




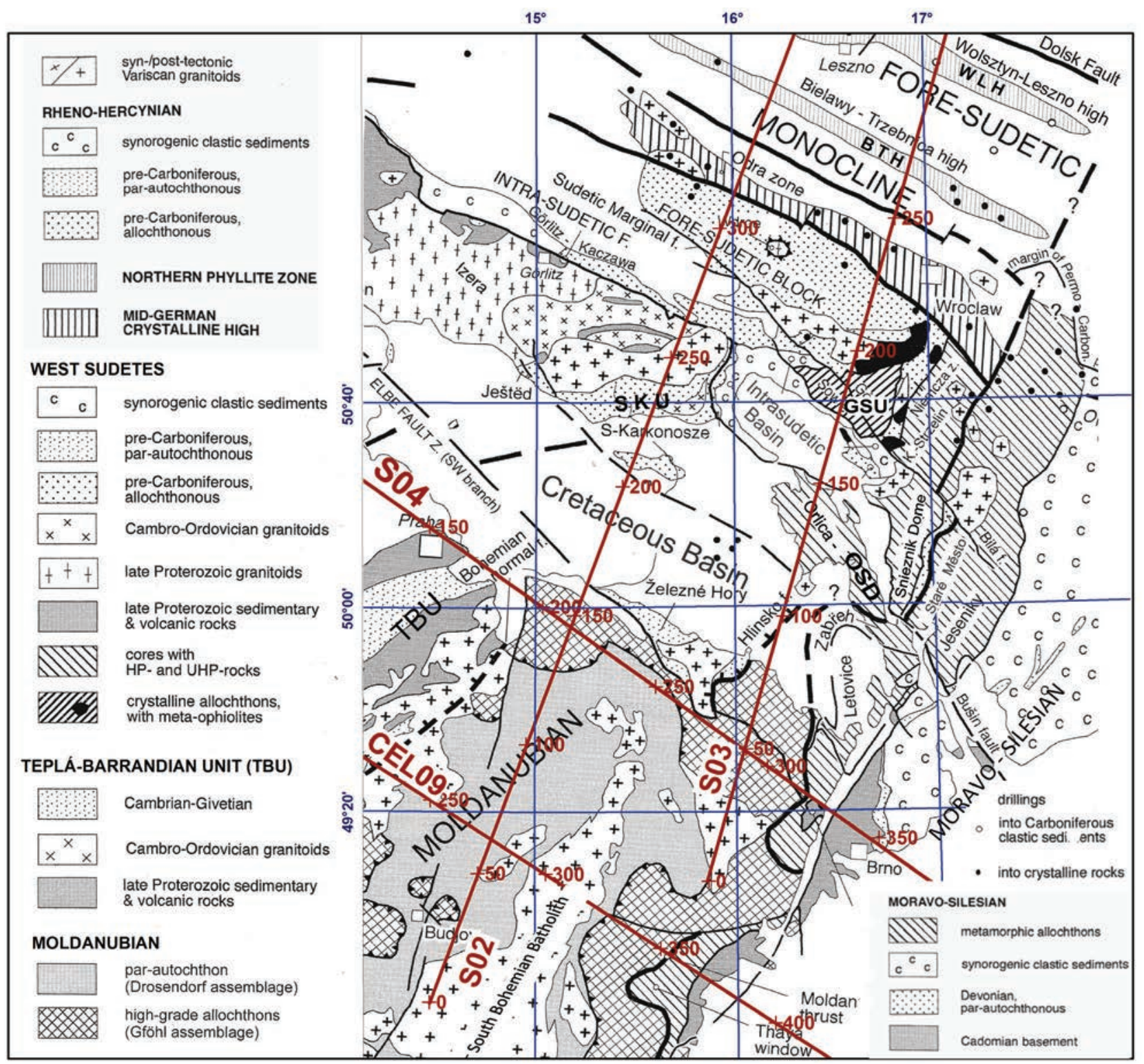

Fig. 3 Structural map of the West Sudetes and Eastern Bohemian Massif after Franke and Żelaźniewicz (2000). The seismic lines are provided by the $50 \mathrm{~km}$ distance ticks. SKU - South Karkonosze Unit, WLH - Wolsztyn-Leszno High, BTH - Bielawy-Trzebnica High. OSD - Orlica-Śnieżnik Dome, GSU - Góry Sowie Unit.

for the simultaneous inversion of both refracted and reflected waves.

Růžek et al. (2007) applied a special inverse method and derived the velocity models along eight profiles crossing the Bohemian Massif. For their non-iterative method, they used the grid cells with the $5 \times 3 \mathrm{~km}$ sizes. Except of P-wave velocities, the models comprised the MOHO discontinuity derived from Pn travel times. Along the CEL09, S04, S02 and S03 profiles, the velocity models also revealed several crustal-scale heterogeneities. In particular, the derived models confirmed the considerable heterogeneity of the S02 and S03 velocity images previously detected by Majdanski et al. (2006). The most pronounced velocity depression, detected along the CEL09 profile, comprises the whole MLD zone.

Guy et al. (2011) successfully verified this CEL09 crustal-scale depression using extended gravity modeling. The authors interpreted the origin of the MLD depression and associated negative Bouguer anomaly as a deep suture formed by the low-density rocks of Saxothuringian felsic crust subducted beneath the adjacent Teplá-Barrandian Unit and exhumed in the Moldanubian Zone.

Novotný et al. (2009) developed an iterative inverse method based on purely refraction data to obtain enhanced P-wave velocity sections. This method, called the Depth-Recursive Tomography on Grid (DRTG) was first applied to the S01 refraction profile (Fig. 1). Its imaging 
ability could be verified down to $9 \mathrm{~km}$ at the KTB super well by means of the vertical seismic profiling and log measurements performed here. In particular, the DRTG imaged the Franconian Fault (Harjes et al. 1997) as a subvertical low-velocity zone that the previous S01 models (Rủžek et al. 2007; Grad et al. 2008) left unresolved. Consistency of the DRTG images at the intersection of the S01 and S04 profiles further allowed their common interpretation involving the granitic and mafic bodies in the Teplice-Altenberg Caldera at the SXT-TBU contact zone (Novotný et al. 2010; Skácelová et al. 2011).

Novotný (2011) further applied the DRTG method to the CEL09 profile. The derived velocity image revealed the subduction features which remained previously unresolved by the ray-tracing modeling of Hrubcová et al. (2005) and also by the non-iterative method of Růžek et al. (2007). The CEL09 velocity section particularly imaged the mafic intrusions shaped by the inclined slab of Saxothuringian crust subducted beneath the TBU (Novotný 2012).

Summarizing the previous approaches, two reasons can be found that led to a reduced resolution of velocity anomalies: (i) the published models attempted to fit simultaneously the reflection and refraction data, although the two exhibit substantially differing uncertainties, (ii) no particular attention was paid to the occurrence of the low-velocity zones (LVZs) which are the cause of inherent ambiguities in refraction imaging. The induced indeterminacy in imaging of even crustal-scale velocity anomalies perhaps lead Majdanski et al. (2006) to omit them in their final crustal models - cf. the critical review by Novotný (2013).

\section{Enhanced refraction tomography}

\subsection{Profile network and targets}

The S02, S03 and transverse S04, CEL09 sections image the subsurface of the western and eastern high-grade MLD belts and the adjacent Sudetic region (Fig. 3). They form an open polygon within the target MLD zone (Fig. 2), the high-grade part of the BM. The SW-NE trending S02 and S03 profiles start in the MLD, continue across the TBU, partly covered by the sediments of the Bohemian Cretaceous Basin. Then they cross the Krkonoše or Orlické hory Mts., Fore-Sudetic block and terminate in the Trans-European Suture Zone. The transverse S04 and CEL09 profiles start in the SXT, then cross the Krušné hory Mts., the SXT and TBU contact zone, Moldanubian (MZ) and Moravo-Silesian (MSZ) zones and then continue to the West Carpathians.

The Moldanubian HP-HT rocks with abundant (ultra-) high pressure $[(\mathrm{U}) \mathrm{HP}]$ granulites and serpentinized gar- net and spinel peridotites form two belts located along the TBU and MSZ boundaries (Fig. 1). In their southern parts (Fig. 3), both belts are separated by the South Bohemian Batholith (SBB). They trend in the SW-NE direction, concordantly with the $\mathrm{S} 02$ and $\mathrm{S} 03$ profiles that further continue to the Sudetes region. The Electronic Supplementary Material A (ESM A1) briefly describes the lithotectonic units, the Gföhl, Ostrong and Drosendorf assemblages involved to these belts. The collateral S02 and S03 profiles and the crossing S04 and CEL09 profiles (Fig 2), provided unique seismic data to explore their crustal architecture on a regional scale.

\subsection{Depth-Recursive Tomography on Grid}

The inverse method "Depth-Recursive Tomography on Grid" (DRTG) is a first-arrival tomography based on the depth-recursive imaging principle (Novotný 1981) that was originally suggested by Claerbout (1971) for imaging subsurface structures by reflection waves. The Claerbout's imaging principle postulates a natural order of subsurface imaging: to proceed consecutively from shallow to larger depths. The medium (rock) properties can then be derived from the wave field extrapolated downward to the zero travel time. The DRTG inversion algorithm incorporates this downward stepping approach. The numerical depth-recursive scheme consecutively calculates the $v\left(x_{i}, Z_{i+1}\right)$ grid values at the depth level $i+1$ whereby the velocities calculated at the previous depths $1,2, \ldots, i$ directly enter the scheme. The recursive procedure is based on a regular network of special refraction probe rays, so-called grid rays, which allows inverting the travel-times to the velocity values at single grid nodes. ESM A2 describes the DRTG method and its resolution ability in a more detail.

\subsubsection{Resolution and sensitivity of tomographic methods}

In the previous tomographic studies, no resolution evaluation has been attempted except for the synthetic checkerboard tests performed by Růžek et al. (2007). The R(x,z) resolvability distributions, obtained from the checkerboard tests, allowed assessing the sensitivity of the ray-based tomographic imaging to the source-receiver geometry of acquired data. The "well-resolved" domains attained $\mathrm{R}(\mathrm{x}, \mathrm{z})>0.6$. From the resolvability computed for the $50 \times 10 \mathrm{~km}$ cells, it follows that the $\mathrm{S} 02, \mathrm{~S} 03, \mathrm{~S} 04$ and CEL09 sections are mostly "well-resolved" (Růžek et al. 2007, their figs 13-14). Regardless of the tomographic method used, the following factors limit the ultimate resolution achievable in any 2-D velocity section:

1) The shot-point deployment determines whether the acquired travel times are representative enough for 
imaging of investigated structures - compare the rule of thumb for a basic resolution in Section 4 that seems to be more adequate than the sensitivity tests with the large, $50 \times 10 \mathrm{~km}$ cells.

2) Occurrences of the LV zones where only average velocities can be derived across them.

3) The travel-times discrepancies in the reciprocal points occurring along the profile lines and other input errors. The reciprocal discrepancies determine adequacy of the seismic profile data to the intended 2-D interpretations.

The velocity models used for geological implications deserve more sophisticated resolution estimates involving LV zones and the reciprocal travel-times discrepancies. The regular network of grid rays used for the DRTG allows such an enhanced resolution estimate - see ESM C.

\subsubsection{Imaging ability}

Any imaging method should prove its imaging ability, i.e., its sensitivity to image near targets. The DRTG was subjected to a spike test imitating a point object (spike) placed into arbitrary model node (Novotný 2011). In dependence on the spline weights used for the depth recursions, the calculated response to such spike excitation showed that the spatial defocusing reached 0.5 to 1.5 multiple of the grid sampling. Spatial smearing of spike targets in the DRTG images then approaches the half-steps of the grid sampling used, i.e. $2.5 \mathrm{~km}$ laterally and $0.25 \mathrm{~km}$ vertically. Consequently, the DRTG method allows resolving two spikes placed in the neighboring grid nodes.

\section{Travel times for the 2-D velocity inversions}

In order to explore the high-grade units in the eastern Bohemian Massif, the S02 and S03 refraction profiles and the first $0-350 \mathrm{~km}$ part of the S04 profile with the densest deployment of the shot points were used (Fig. B1 and Tab. B1 in ESM B). Prevailingly, the single-channel REFTEK-125 stations with $4.5 \mathrm{~Hz}$ geophones were employed to record the vertical component of seismic amplitudes sampled at $10 \mathrm{~ms}$. ESM B summarizes the refraction data and their basic processing involving staticcorrections and input-errors analyses. Table B1 lists the processed shot points. The $\mathrm{Y}$ and $\mathrm{Z}$ coordinates in the table mean their side deviations from the profile line and altitudes. The X coordinates correspond to the straightened profile lines fitting the receiver and shot-point positions. The $\mathrm{X}$ also define the distance scales in the output velocity sections. The side uncertainties in the S02 and S03 sections are increased by the transverse shifts in the
S02 and S03 receiver deployments occurring at the Polish-Czech border (see fig. 2 in Majdanski et al. 2006).

The processed part of the S04 profile includes 13 shot points yielding an average inter-shot distance of $31.4 \mathrm{~km}$ with a maximum gap of $56.9 \mathrm{~km}$ at $\mathrm{km} \mathrm{228}$. Similarly, the average inter-shot distances of the S02 and S03 shot points are 55.0 and $43.5 \mathrm{~km}$ with maximum gaps of 69.6 or $57.6 \mathrm{~km}$ at the $\mathrm{km} 182$ or 223 , respectively. The shotpoint deployments are significant for the real lateral resolution that can be roughly estimated by a rule of thumb: a target can be laterally resolved if it influences at least two travel-time curves or their branches. It means that the distinguishable targets must be larger than half the average inter-shot distance, i.e., $15.7,22.5$ and $21.7 \mathrm{~km}$ for profiles $\mathrm{S} 04, \mathrm{~S} 02$ and $\mathrm{S} 03$, respectively. The resolution attained can be in fact better for targets deeper that can be hit by more than two travel-time branches (Fig. B2 in ESM B). On the contrary, the near-surface targets are laterally resolved twice worse. For the offsets of measurement $q$ approaching zero, two travel-time branches due a shotpoint namely merge into one at the surface (Fig. B2). Consequently, the near-surface targets are resolved at the whole average inter-shot distances.

The SUDETES 2003 profiles pass several mountain ranges with the altitudes of $800-1000 \mathrm{~m}$ descending to 160-70 $\mathrm{m}$ in the lowlands (Fig. B1). To remove the influence of the surface topography and weathering layer on the imaged structures, the static corrections were calculated and applied (ESM B). Table B2 summarizes the basic characteristics of the complete static corrections (DTRS) obtained as the sum of the receiver (DTR) and shot-point (DTS) corrections for each source-receiver pair. The ESM B further describes the processing of the travel-times picked along the individual profiles. The picked refraction arrivals $t(p, q)$ were arranged according to their midpoint position $p$ and offset of measurement $q$. Figure B2 presents the systems of static-corrected traveltimes constraining the resulting time lines $t\left(p, q_{n}\right)$ along the S04, S02 and S03 profiles. Using the splines with controlled smoothing, the time lines were rid of smallscale details beyond the expected resolution. A useable part of the input data domains is trapezium-shaped. The imaging refraction rays have then at least one-half of their paths within the mapped domain. Note two blind ranges with no refraction data at the beginning of the $\mathrm{S} 02$ and S03 profiles (Fig. B2). They signalize occurrences of low-velocity zones with no refraction returns.

The obtained time lines $t(p, q), q=q_{n}$ are used to constrain the velocity models. The time lines $t(p, q)$ are monotonically increasing functions in the offset variable $q$ for any fixed midpoint $p_{m}$. The initial 2-D velocity models in the DRTG iterations were inferred from the set of the equal-midpoint travel-time curves, $t(p, q), p=p_{m}$. The concept of time lines also allows an easy interpolation of 
the travel times for the imaging grid rays whose emergence points do not generally coincide with the original source and receiver positions of field measurements.

The last section "Input data errors" in ESM B analyses sources of input errors. The analyses revealed that the largest root-mean-square (RMS) errors are due to the discrepancies at the reciprocal points of field measurements. They reach 117, 106 and $75 \mathrm{~ms}$ in the S04, S02 and S03 data sets, respectively. Since the resulting input data errors cannot be less, these values mean the thresholds to which the pre-processed S04, S02 and S03 travel times can effectively constrain the 2-D models.

\section{Inversion of refraction data}

The velocity models along the S04, S02 and S03 profiles will be derived applying the DRTG method recapitulated in ESM A. An integral part of the DRTG is calculation of the travel-time residuals at all model grid nodes followed by statistical estimation of the $1 \sigma$ or $2 \sigma$ lateral resolution - see ESM C. In conformity with the input data sets, the grid steps $\Delta \mathrm{x}=5000 \mathrm{~m}$ and $\Delta \mathrm{z}=500 \mathrm{~m}$ were chosen for all velocity models. The $500 \mathrm{~m}$ step is also used for the depth-recursive calculations. The high ratio of $\Delta x / \Delta z=10$ allows applying a fast-explicit solver for the tomographic equations with satisfactory accuracy (Novotný 2011).

The ray-based tomographies use an approximate linearized relation between the travel-times fit of a starting model and the slowness corrections for the successive model updating. The concept of grid rays used in the DRTG allows inferring the travel-time fit $\Delta t\left(x_{i}, z_{j}\right)$ and corresponding velocity correction $\Delta v\left(x_{i}, z_{j}\right)$ at each model node $\left(x_{i}, z_{j}\right)$ - see Fig. A1 in ESM A. The linearization errors inherently increase with the depth. Their suppression is a matter of iterations: each updated model serves as the starting model for the following iteration. Simultaneously, the starting models are verified by repeated determination of the travel-times fits $\Delta t\left(x_{i}, z_{j}\right)$. The travel-times fit $\Delta t\left(x_{i}, Z_{j}\right)$ achieved for the last-updated model is then used for the statistical evaluation of the lateral resolution.

Two criteria are applied to assess the DRTG iterations with the depth. One represents the standard deviation $\sigma(z)$ of the travel-time fits $\Delta t\left(x_{i}, z\right)$ due to the $N(z)$ refraction rays bottoming at the $z$ level. The second criterion is the specific RMS time fit related to a grid ray, i.e. $\sigma_{s}(z)=$ $\sigma(z) / N(z)$. Both criteria are necessary because the standard deviation $\sigma$ is practically insensible to the varying number of successful refraction rays. If more models yield the same value of the standard deviation $\sigma(z)$ at a particular depth, those with a greater number of successful grid rays $N(z)$ and then yielding a smaller specific $\sigma_{s}(z)$ should be preferred. However, the $\sigma_{s}(z)$ criterion cannot be applied alone because it locally fails whenever low-
Tab. 1 The depth-averaged RMS time fits per a grid ray attained on the S04 profile during the updating iterations

\begin{tabular}{cccccc}
\hline \multirow{2}{*}{$\begin{array}{c}\text { Iteration } \\
\text { number }\end{array}$} & $\begin{array}{c}\text { Starting } \\
\text { S04 models }\end{array}$ & \multicolumn{2}{c}{$\begin{array}{c}\text { RMS per a grid ray } \sigma_{\mathrm{s}} \text { in } m s \\
\text { averaged over depths }\end{array}$} & $\begin{array}{c}\text { RMS } \\
\sigma \text { in } \mathrm{ms}\end{array}$ \\
\cline { 3 - 6 } & $0-5 \mathrm{~km}$ & $0-10 \mathrm{~km}$ & $0-15 \mathrm{~km}$ & $0-15 \mathrm{~km}$ \\
\hline 1 & $1-\mathrm{D}$ & 3.888 & 4.383 & 4.135 & 273.1 \\
2 & VM1 & 1.341 & 4.518 & 15.423 & 177.7 \\
3 & VM2 & 1.606 & 2.802 & 6.516 & 155.8 \\
4 & VM3 & 1.826 & 2.795 & 4.761 & 131.5 \\
5 & VM4 & 1.587 & 9.500 & 8.663 & 116.8 \\
\hline
\end{tabular}

The RMS per a grid ray is assessed over the $0-5,0-10$ and $0-15$ depth ranges. Last column presents the total RMS averaged over the $0-15$ km. See also Fig. 4

velocity zones (LVZ) with no returns of refraction rays occur. Therefore, both criteria were applied together. In the following sections, the results of the DRTG iterations achieved for individual profiles are summarized.

\subsection{S04 profile}

Several consecutive DRTG iterations were performed to invert the input S04 travel times (Fig. B2 in ESM B) to the P-wave velocities. As an initial model VM0, a highly simplified 1-D velocity model was employed that was obtained by the Wiechert-Herglotz transform of travel-times averaged along the S04 profile. The grid rays, generated for VM0, yielded the first set of velocity corrections. After their introduction to the VM0, the updated 2-D model was obtained. This VM1 model served as the starting one in the next iteration and so on. The iteration process was controlled by the specific $\sigma_{s}(z)$ and standard $\sigma(z)$ deviations of the achieved travel-time fits $\Delta t\left(x_{i}, z\right)$.

To illustrate the behavior of linearization errors, specific $\sigma_{s}(z)$ and standard $\sigma(z)$ deviations averaged for three depth ranges were calculated (Tab. 1). Figure 4 illustrates the overall RMS fits achieved during the iterations. The initial 1-D model has a perfect $100 \%$ ray coverage and the best $\sigma_{s}$ value of $4.135 \mathrm{~ms}$ but its overall RMS fit is the

\section{Depthraveraged RMS per a grid ray}

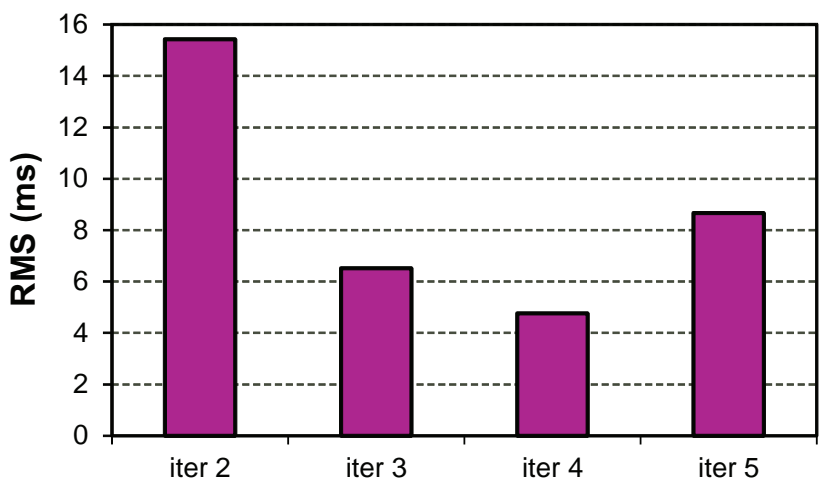

Fig. 4 The depth-averaged RMS fits per a grid ray during the DRTG iterations of S04 models. 
$\rightarrow$ Best updated $\sim$ Final model optimized for LVZ

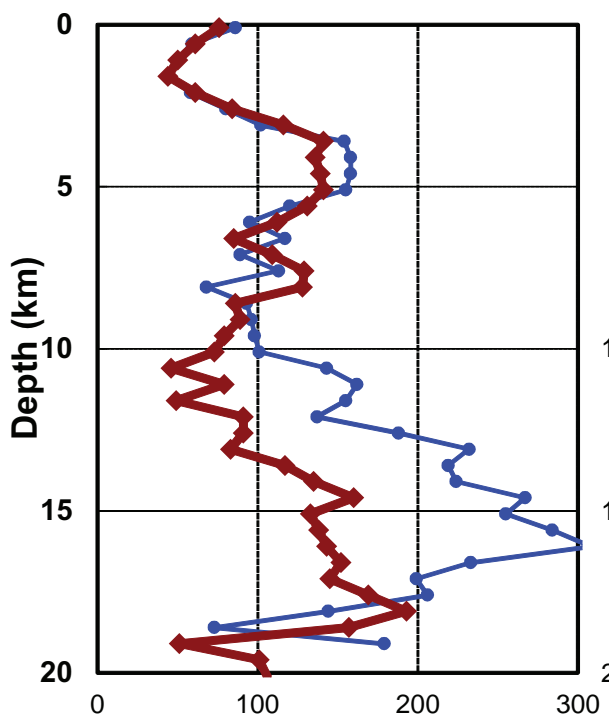

RMS travel-time misfit (ms)

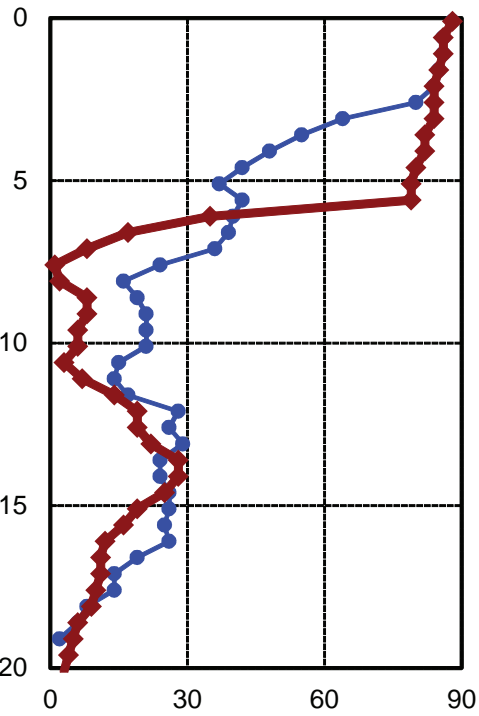

Number of grid rays

\section{S04 horizontal resolution}

of $10 \%$ and $5 \%$ velocity anomalies

Fig. 5 The S04 depth curves of the RMS travel-time fits, numbers of successful grid rays and resolution curves at the 95\% confidence level. (1) - the best-updated VM3 model; (2), (3) - its VM3w11 and VM3wz versions. The right panel presents the lateral sizes of 10\% and 5\% velocity anomalies resolved at the $95 \%$ confidence level in the (3) final model. The red "Limit" curve stands for the mean distance among the verified model nodes.

worst one $(273 \mathrm{~ms})$. On the contrary, for the whole depth range of $15 \mathrm{~km}$, the last updated model VM4 displays a minimum overall RMS of $116 \mathrm{~ms}$ but its poorest ray coverage yields the worst $\sigma_{s}(z)=8.663 \mathrm{~ms}$. Therefore, the VM3 model with the overall RMS of $131.5 \mathrm{~ms}$ is a reasonable compromise - see Tab. 1. Its specific fit 4.761 $\mathrm{ms}$ (over $0-10 \mathrm{~km}$ even $2.795 \mathrm{~ms}$ ) is due to a grid-ray coverage of $\sim 60 \%$ against the initial 1-D model.

The attempts to improve the ray coverage by model smoothing are not desirable if LV zones with the depthdecreasing or constant velocities occur. The iterative DRTG inversions of the S04 time lines repeatedly proved multiple occurrences of LVZ at the $6-11 \mathrm{~km}$ depths. To conserve them, a more sensitive smoothing, weaker over this depth range, was applied. Figure 5 and Table 2 illustrate the results on three output models VM3, VM3w11 and VM3wz denoted as (1), (2) and (3), respectively. The VM3w11 and VM3wz models were inferred from

Tab. 2 The RMS time fits per a grid ray $\sigma_{s}(z)$ averaged over the depths of 0-6, 6-11 and $11-15 \mathrm{~km}$ for three S04 models

\begin{tabular}{ccccc}
\hline \multirow{2}{*}{ S04 models } & \multicolumn{3}{c}{ RMS per a grid ray in $\mathrm{ms}$} & RMS in $\mathrm{ms}$ \\
& $0-6 \mathrm{~km}$ & $6-11 \mathrm{~km}$ & $11-15 \mathrm{~km}$ & $0-15 \mathrm{~km}$ \\
\hline$(1)$ & 1.912 & 4.528 & 8.816 & 132 \\
$(2)$ & 1.998 & 4.083 & 13.869 & 176 \\
$(3)$ & 1.195 & 27.737 & 5.615 & 99 \\
\hline
\end{tabular}

(1) the best-updated model VM3, (2) after smoothing with a fixed spline weight $\mathrm{w}=11$ and (3) after applying the depth-dependent weight $\mathrm{w}(\mathrm{z})$ preserving the LVZs in the mid-depth range. See Fig. 6 for column graphs the best-updated model VM3 by its smoothing with the constant $w=11$ or depth-dependent $w(z)$ spline weights. Figure $\mathrm{C} 1$ in ESM C images them at the $100 \mathrm{~m} / \mathrm{s}$ contour step. Figure 5 shows the standard deviations $\sigma(z)$ achieved by the successful grid rays whose numbers $N(z)$ are depicted in the mid-panel. The right panel presents the horizontal resolution of 5\% and $10 \%$ velocity anomalies inferred for the final model (3) at the 95\% confidence. According to Equation (C4) in ESM C, the 10\% velocity anomaly curve also expresses the lateral resolution for the $5 \%$ anomalies at the lower $68 \%$ confidence.

The LV zones remained best preserved in the final model (3) owing to lower smoothing applied in the 6-11 $\mathrm{km}$ depths - compare all models in Fig. C1. Consequently, this model displays a significantly improved fit below $11 \mathrm{~km}$ and strongly reduced resolution in the upper conserved LV belt - see the "Limit" resolution curve diverging at the 6-11 km depths (Fig. 5). The $\sigma_{s}(z)$ values diverged to $\sim 28 \mathrm{~ms}$ (Tab. 2) beyond the column graph in Fig. 6. Note that the intermediate model (2) smoothed with a fixed spline weight $w=11$, produced a better ray coverage of the $6-11 \mathrm{~km}$ depths but spoiled the performance in the lower depth range. However, sweeping out the LV zones from the $6-11 \mathrm{~km}$ depths caused a serious distortion of the velocity image since its overall traveltime misfit reached the largest value of $176 \mathrm{~ms}$ (Tab. 2).

To illustrate the refraction tomography ambiguities, Fig. C1 collects all the discussed versions of the S04 models. An important characteristic is the attained ray 


$$
\square Z=0-6 \mathrm{~km} \mathrm{\square Z}=6-11 \mathrm{~km}(\text { LVZ) } \square Z=11-15 \mathrm{~km}
$$

Fig. 6 The $\sigma_{s}$ travel-time fits per a grid ray achieved along the S04 profile. Depicted are the averages for three depth ranges, the middle range involves major LV zones. The best-updated VM3 model is compared with its two versions, VM3w11 and VM3wz smoothed with the $w=11$ fixed weight (optimized) or $w(z)$ the depth-dependent weight (optimized for $L V Z$ ) preserving the $\mathrm{LV}$ zones. A considerable improvement of the RMS fit beneath the LVZ belt was achieved in the final VM3wz model (see also Tab. 2).

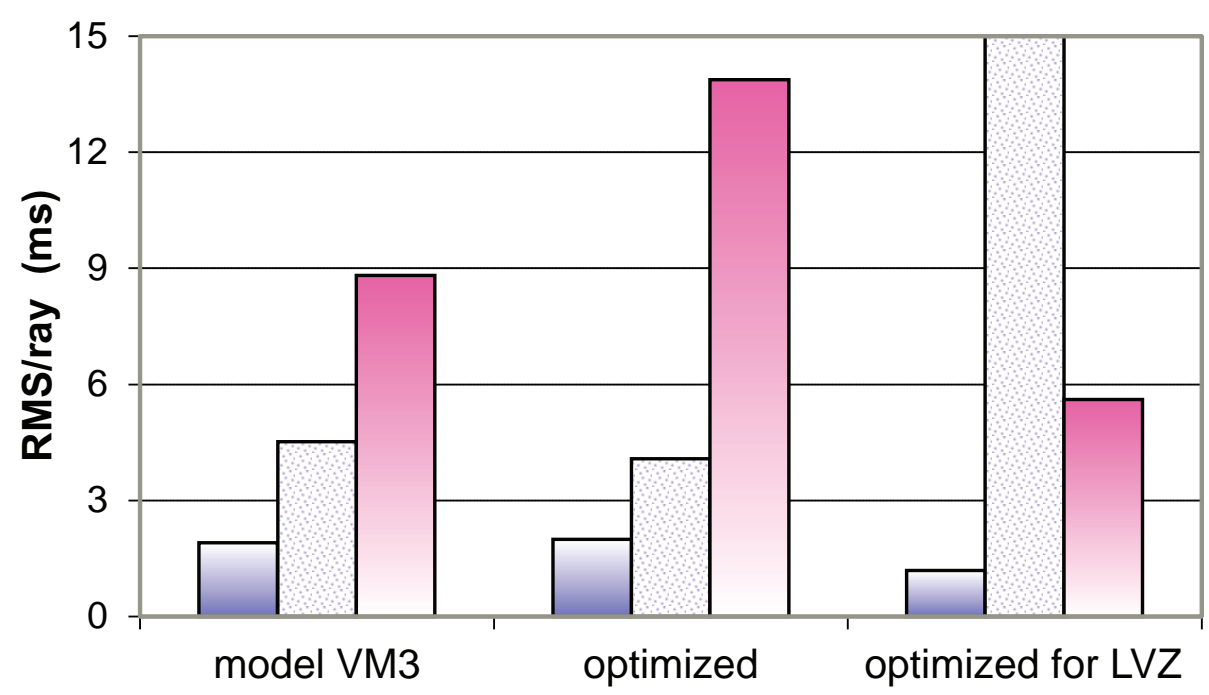

coverage depicted by dots in the verified grid nodes. The dots stand for the bottoms of the grid rays yielding the final travel-time fit. The verified (dotted) parts of the individual models are bordered by thick white lines. Empty grid nodes mostly mark the occurrences of the very weak or negative velocity z-gradient from where the refraction rays cannot return to the surface. One can observe that smoothing reduces minor details and sweeping out of LV zones. The ray coverage then depends on the smoothing measures applied.

A disadvantage of refraction tomographies is that they can detect LV zones only indirectly; their account may improve the travel-time fits for the passing, deeper bottoming refraction rays. In the final S04 model, such a fit improvement can be observed (Fig. 5) for the velocity features beneath the 6-11 km LV belt. After accounting $\multimap$ Best updated $\quad$ Final model optimized for LVZ

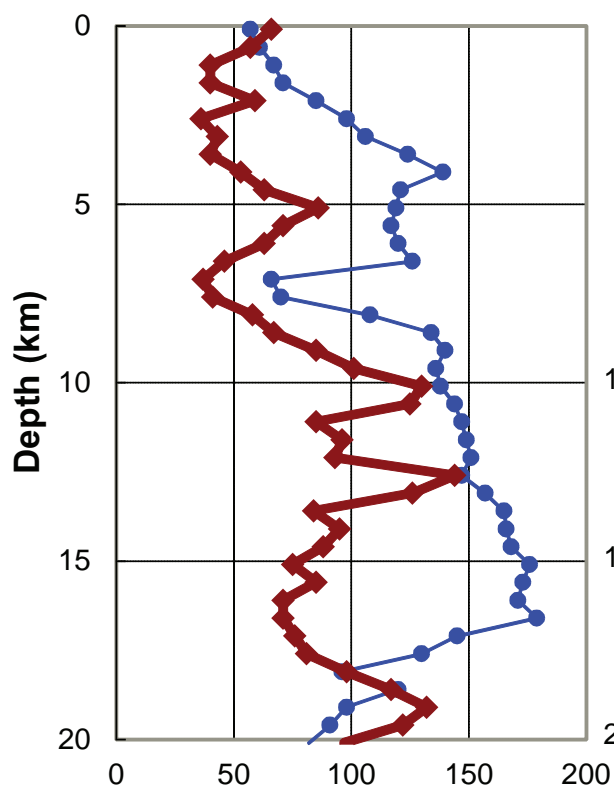

RMS travel-time misfit (ms)

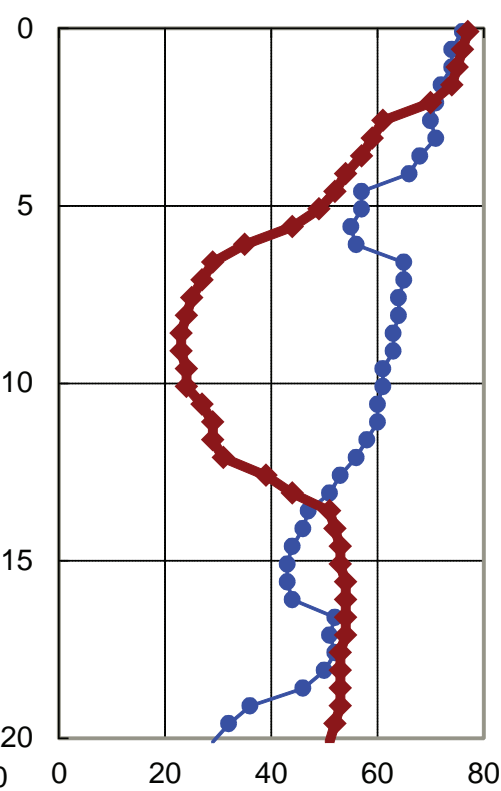

Number of grid rays
S02 horizontal resolution

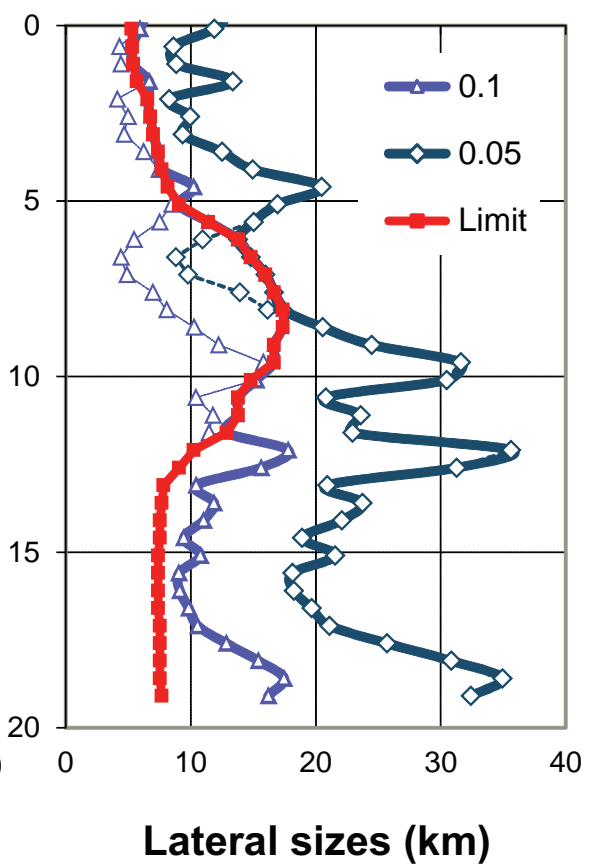

Fig. 7 The S02 depth curves of the RMS travel-time fits, numbers of successful grid rays calculated for the best-updated and the final model preserving the LV zones. The right panel presents the lateral sizes of $10 \%$ and $5 \%$ velocity anomalies resolved at the $95 \%$ confidence level in the final model. The red "Limit" curve shows the mean distance among the verified grid nodes. 
$\rightarrow$ B est updated $\rightarrow$ F inal model optimized for LVZ

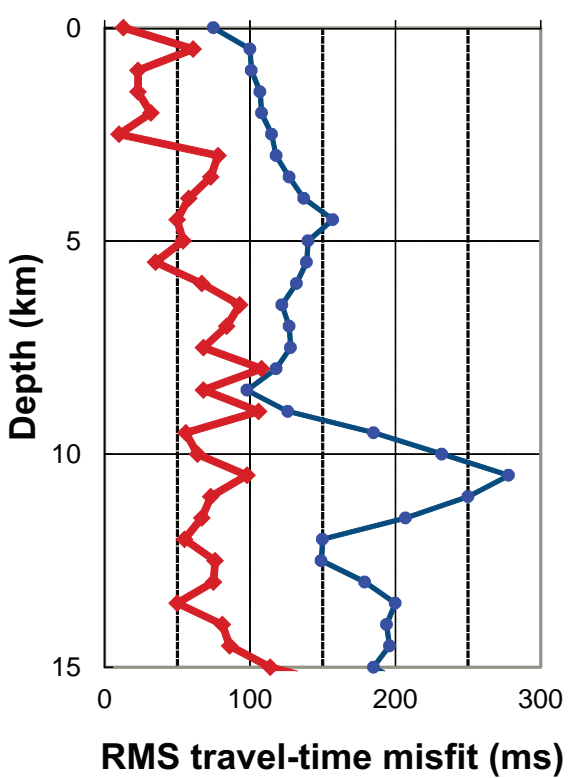

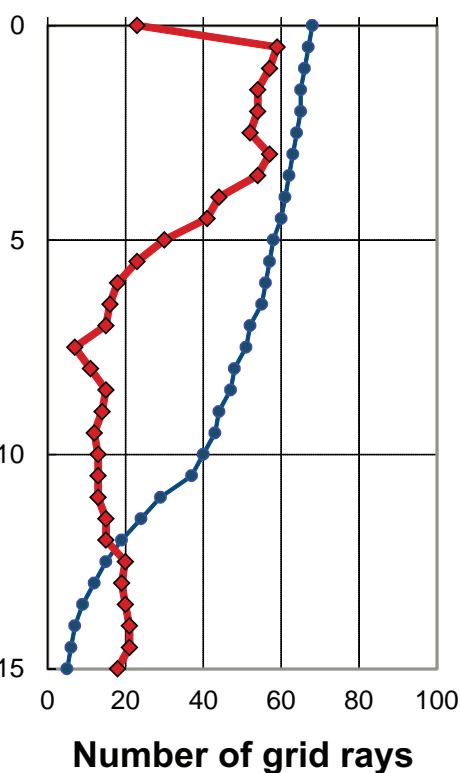

S03 horizontal resolution for $10 \%$ and $5 \%$ relative velocity anomalies

Fig. 8 The S03 profile - for description see the previous Fig. 7.

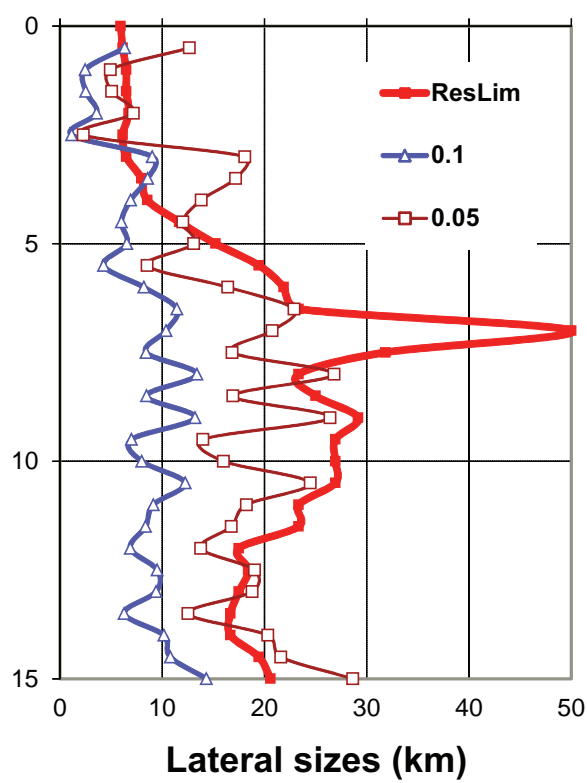

the LV zones in model (3), the overall RMS fit of the best-updated model (1) is improved from $132 \mathrm{~ms}$ to 99 ms, i.e., by $25 \%$ (Tab. 2). Another test of the improved performance of the final S04 model is provided at the crossing with the S02 model. The best agreement just shows the VM3wz model - compare the isolated highvelocity (HV) body and underlying LV zone at the profile intersection (Figs $\mathrm{C} 1$ and $\mathrm{C} 2$ ).

\subsection{S02 and S03 profiles}

The DRTG inversion was iteratively applied to the S02 and S03 input travel times (Fig. B2). The best-updated models according to both $\sigma(z)$ and $\sigma_{s}(z)$ criteria were further smoothed and tested for better conserving the LV zones that repeatedly appeared in higher iterations. Figures 7 and 8 illustrate the results for the best updated models and their final versions optimized for LV zones. The figures present the $\sigma(z)$ standard deviations achieved, $N(z)$ numbers of the successful grid rays and the lateral resolution inferred from $\sigma(z)$ as described in ESM C. The decrease of $N(z)$ in the $6-11 \mathrm{~km}$ depths on both profiles again indicates the occurrence of LV zones causing a

Tab. 3 The RMS time fits, Nray numbers of rays and relative ray coverage calculated for the best-updated and final S02 and S03 models preserving LV zones

\begin{tabular}{lcccccc}
\hline \multirow{2}{*}{ Models } & \multicolumn{2}{c}{ S02 profile (depths $0-20 \mathrm{~km})$} & \multicolumn{3}{c}{ S03 profile (depths $0-15 \mathrm{~km})$} \\
& RMS $(\mathrm{ms})$ & Nray & coverage & RMS $(\mathrm{ms})$ & Nray & coverage \\
\hline Best updated & 123 & 2326 & $100 \%$ & 153 & 1359 & $100 \%$ \\
Final & 79 & 1921 & $83 \%$ & 68 & 861 & $63 \%$ \\
\hline
\end{tabular}

local loss of lateral resolution. Involving the LV zones considerably improved the overall travel-times fits of the final models (Tab. 3).

Figures C2 and C3 illustrate the output of S02 and S03 velocity models. The geological background depicted comprises regional fault zones and Sudetic terranes after Mazur et al. (2006), Scheck et al. (2002) and Majdanski et al. $(2006,2007)$. The upper panels present the bestupdated models. The final models preserving LV zones (bottom panels) show considerably better RMS fits not only beneath the LVZ belts at 6-11 km (Figs 9 and 10) but also for the whole models. The substantially better fits by 36 and $56 \%$ (Tab. 3) mostly led to emphasizing the velocity features that were previously blurred (Figs C2 and C3). The derived DRTG velocity models were compared with the previous modeling results published in Geissler et al. (2012), Hrubcová et al. (2005, 2010), Růžek et al. (2007) and Majdanski et al. (2006). The common and diverse features are discussed in ESM C.

\subsection{Lateral resolution achieved in the velocity sections}

The grid rays yield the traveltime fit at each model node which allows deriving the minimum lateral sizes of the "yet resolvable" anomalies whose responses would emerge above the travel-time residua un- 
Moldanubian

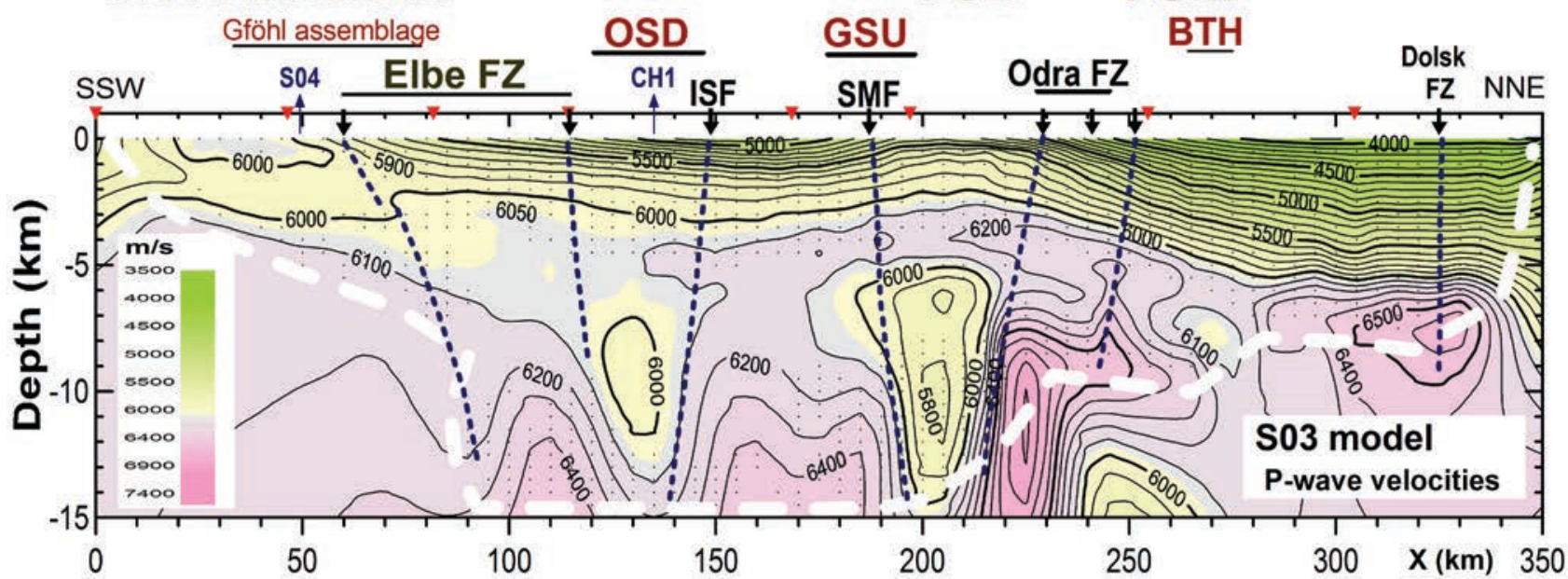

Fig. 9 The final S03 model with the $68 \mathrm{~ms}$ RMS fit attained at the marked nodes. The P-wave isovelocities are in the $100 \mathrm{~m} / \mathrm{s}$ step. The thick white line borders the verified model nodes. Faults and unit boundaries: FZ - fault zones; OSD - Orlica-Śnieżnik (Sněžník) Dome, GSU - Góry Sowie Unit, FSB - Fore Sudetic Block, FSM - Fore Sudetic Monocline, BTH - Bielawy-Trzebnica High, ISF - Intra-Sudetic Fault, SMF - Sudetic Marginal Fault. S04, CH1 - intersections with other profiles.

matched after tomographic imaging. The DRTG achieved the total RMS travel-time fits of 99,79 and $68 \mathrm{~ms}$ in the final S04, S02 and S03 sections, respectively (Tabs 2-3). The travel-time fits evaluated at single depth levels (left panels in Figs 5, 7-8) then allow inferring the depth curves of lateral resolution (ESM C). By means of Equation (C2), the depth curves of the $2 \sigma$ lateral resolution for two relative velocity anomalies of $r_{a n}=10$ and $5 \%$ were calculated. They are presented in the right panels of Figs 5, 7-8. According to Equation (C4), the presented graphs derived for the $10 \%$ velocity anomaly (triangle symbols) and $95 \%$ confidence $(2 \sigma)$ also represent the $1 \sigma$ resolution of the more frequently occurring $5 \%$ velocity anomalies at the lower, $68 \%$ confidence. Note that the velocity anomalies, resolved with the lower $68 \%$ confidence, allowed a reliable interpretation at the KTB super-drilling hole (Novotný et al. 2009).

The lateral resolution according to Equation (C2) is naturally valid if the statistical assumptions (such as a sufficient number of rays) are not violated. Regardless of $\sigma(z)$ achieved at a particular depth $z$, the anomalies uncovered by the grid rays can be hardly resolved. Therefore, all the DRTG velocity sections (Figs 9-11) are provided with the dots in the bottoms of successful imaging rays. Moreover, as a superior resolution limit, the average distances between the grid-rays bottoms at each z level

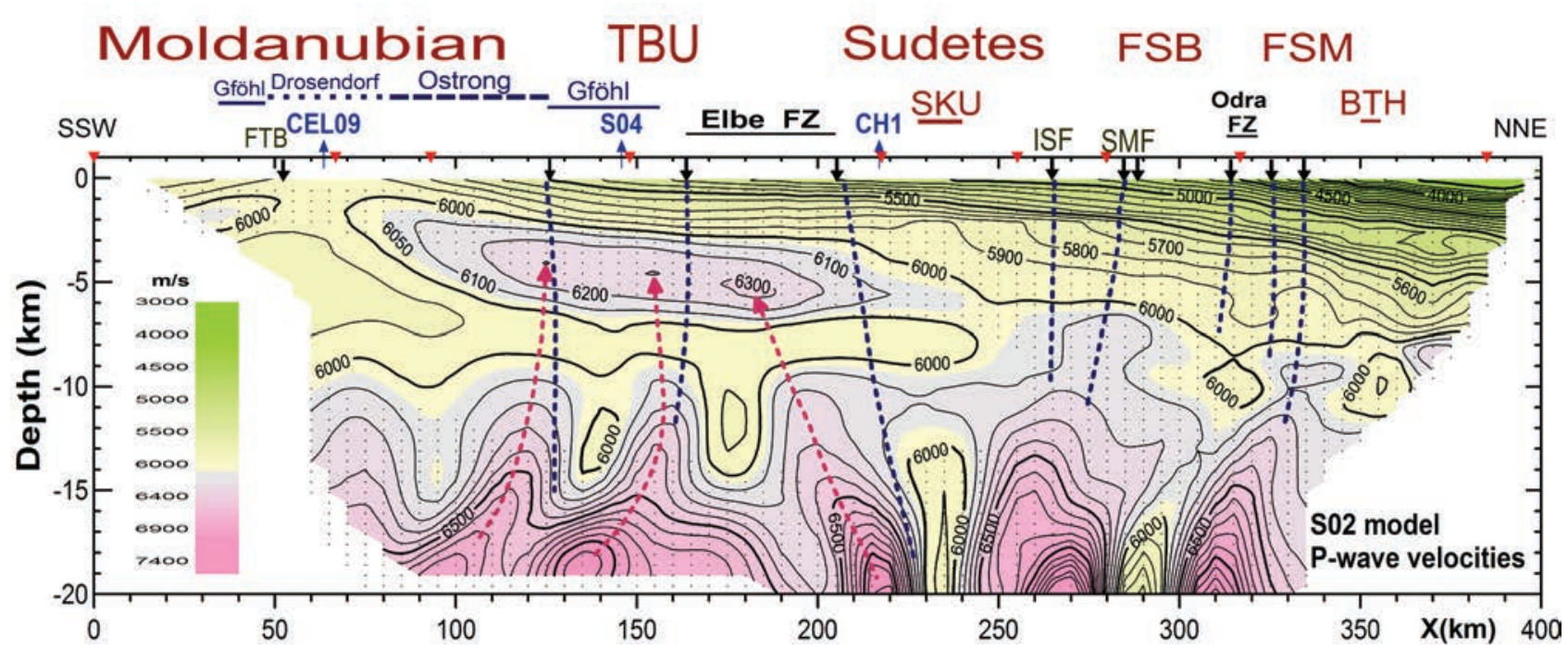

Fig. 10 The final S02 model with the 79 ms RMS fit attained at the marked nodes. Faults and unit boundaries involved: FTB - eastern marginal fault of Třeboň Basin; Odra FZ - Odra Fault Zone; ISF - Intrasudetic Fault; SMF - Sudetic Marginal Fault; SKU - South Krkonoše Unit; FSB - Fore Sudetic Block; FSM - Fore Sudetic Monocline; BTH - Bielawy-Trzebnica High. CEL09, S04, CH1 - intersections with other profiles. 


\section{SAXOTHURINGIAN TEPLÁ-}
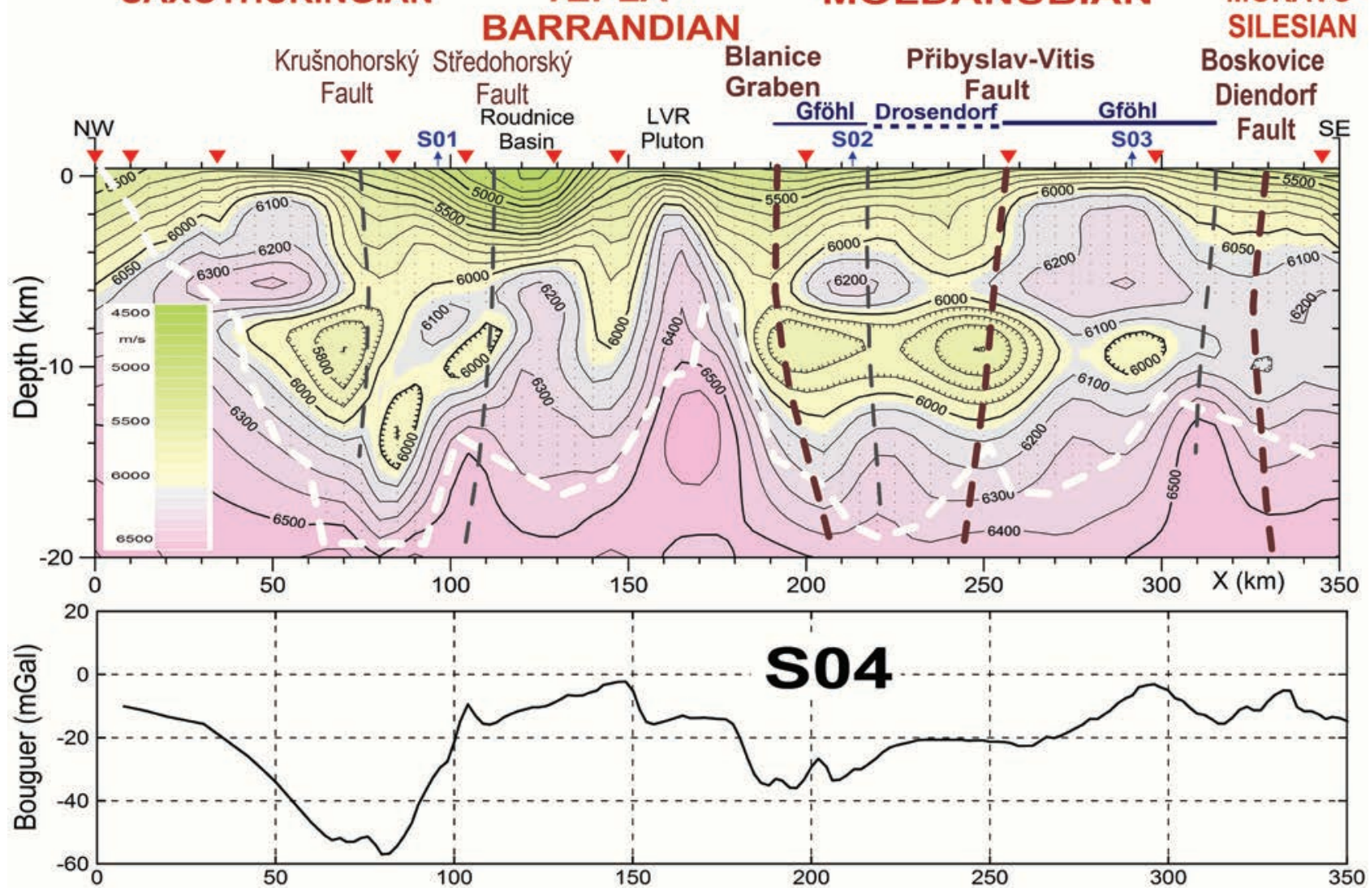

Fig. 11 The final S04 model with the 99 ms RMS fit attained at the marked model nodes. Bottom are depicted the Bouguer anomalies. Faults and unit boundaries are indicated according to Fig. 3 and Novotný et al. (2010). LVR Pluton - Lower Vltava River Pluton (Fediuk 2005).

are added in Figs 5, 7-8. This limit approaches the grid $\mathrm{x}$-sampling of $5 \mathrm{~km}$ if the $100 \%$ ray coverage is attained. The intermediate $6-11 \mathrm{~km}$ depth range shows a strongly reduced ray coverage due to the frequent occurrence of LV zones resulting in a poor resolution. However, certain resolution occurs locally in the sub-domains with the verified nodes (dotted). A detailed interpretation should regard the dotless areas in Figs 9-12 meaning the local dropouts in the ray coverage.

The lateral resolution at the $68 \%$ confidence achieved in single profiles can be summarized as follows. At the shallow depths of $0-6 \mathrm{~km}$, the $5 \%$ velocity anomalies in the S04, S02 and S03 images are resolved, if their lateral sizes exceed (depending on their depths) 5-17, 7-10 and $7-20 \mathrm{~km}$, respectively. Similarly, at the depths beneath 11 $\mathrm{km}$, the lateral sizes of the resolvable $5 \%$ anomalies range between $20-40,18-10$ and $18-28 \mathrm{~km}$ (Figs $5,7-8$ ). The intermediate $6-11 \mathrm{~km}$ depths show a drop in resolution due to the multiple LV anomalies occurring in all the profiles. However, accounting for this LV zone improved the S04, S02 and S03 total travel-time fits by 25,36 and $56 \%$ and yielded an enhanced resolution beneath $11 \mathrm{~km}$. In particular, three mid-crustal diapiric S02 anomalies $\sim 25 \mathrm{~km}$ wide (200-340 km in Fig. 10), are imaged with a confidence even higher than $95 \%$. Their relative velocity excesses reach $\sim 10 \%$, for which the resolvable sizes at the $95 \%$ confidence level and $20 \mathrm{~km}$ depth, approach 18 km (Fig. 7), then less than $25 \mathrm{~km}$.

\section{Interpreting the velocity patterns}

The P-wave velocities ( $\mathrm{Vp}$ ) depend on the mineral composition, conditions (laboratory or in situ) and rock anisotropy. In general, $\mathrm{Vp}$ decreases with increasing content of silicate minerals. To get an idea concerning the Earth's crust composition, one can refer to two global models. Rudnick and Gao (2003) suggested a three-layer model while later, Hacker et al. (2011) assumed two-layer Earth's crust. The models operate with different mantle heat flows, 17 vs. $11 \mathrm{~mW} / \mathrm{m}^{2}$, respectively. Hacker et al. (2011, tab. 1) considered 65.2 wt. \% of $\mathrm{SiO}_{2}$ as an average for their two-layer crust. In comparison with the three-layer model, Hacker et al. (2011) proposed the lower crust to be significantly more acidic (64 vs. 53 wt. $\%$ of $\mathrm{SiO}_{2}$ ) and three times more radiogenic.

For felsic gneiss samples containing $\sim 65.4$ wt. \% of $\mathrm{SiO}_{2}$, Rudnick and Fountain (1995) and Kanao and 

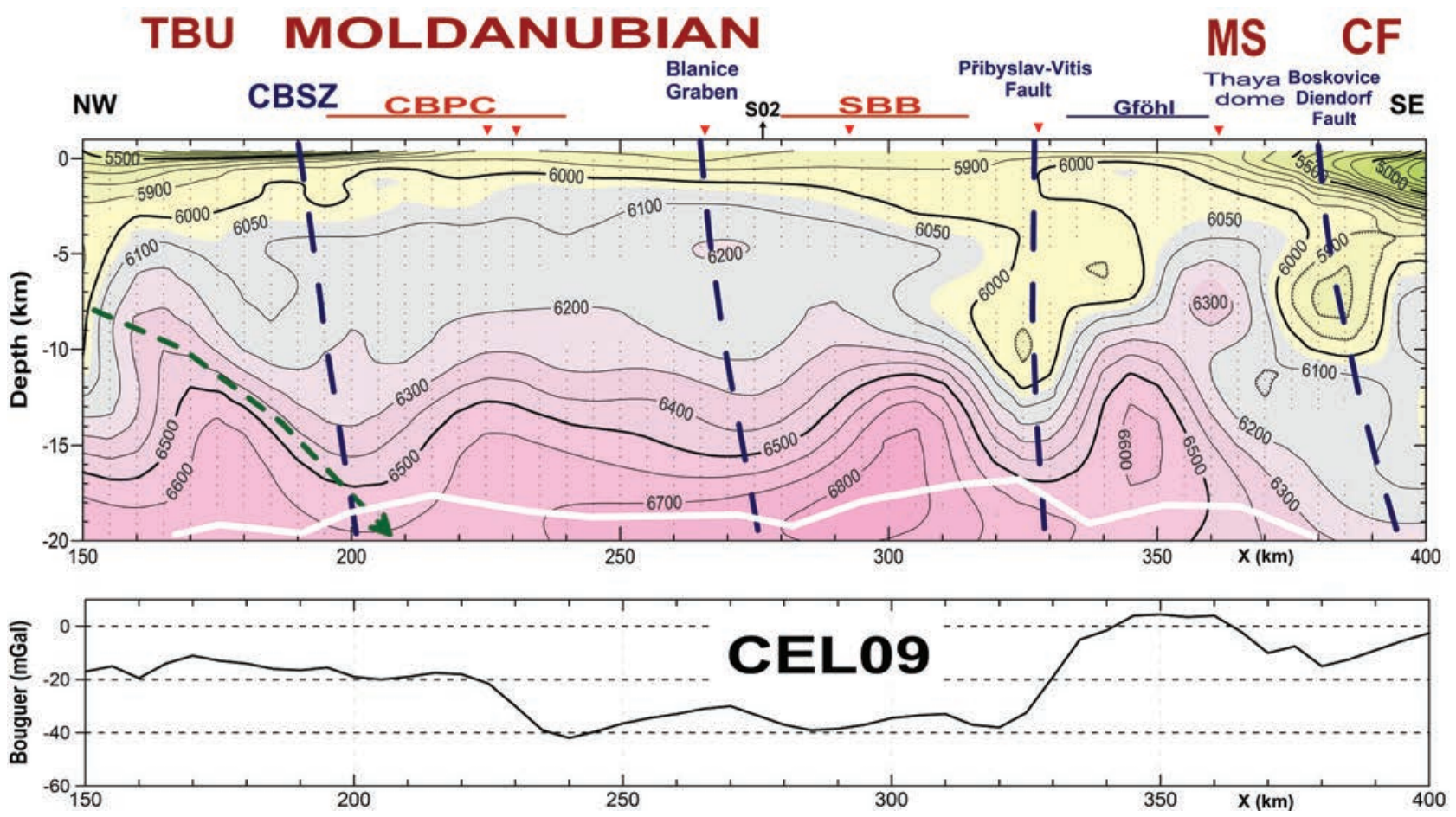

Fig. 12 The P-wave velocities and Bouguer anomalies along the CEL09 profile (Novotný 2012). The model fits the travel times at the marked grid nodes with an overall RMS of $97 \mathrm{~ms}$ (Novotný 2011). The regional faults (dashed) follow the deep depression zones. The detachment surface of the SXT subducted slab beneath TBU is traced as an interface (dashed arrow) between the vertical and inclined parts of the post-kinematic intrusions. The unit boundaries and major faults correspond to Fig. 3. CBSZ - Central Bohemian Shear Zone, CBPC - Central Bohemian Plutonic Complex, SBB - South Bohemian Batholith, MS - Moravo-Silesian Zone, CF - Carpathian Foredeep.

Ishikawa (2004) reported ultrasonic Vp of 5.9-6.2 km/s at pressures of 0.1-0.3 GPa. Brownlee et al. (2011) obtained a similar Vp range of $5.8-6.3 \mathrm{~km} / \mathrm{s}$ for gneiss samples at higher pressures, up to $0.6 \mathrm{GPa}$. For the gneiss samples without hornblende, the authors reported a low Vp anisotropy, between 1.3 and $3.1 \%$. However, the hornblendebearing samples exhibited more anisotropic behavior, 5.3-8.6 \%. With increasing temperature and pressure, felsic gneisses can show an inverse, decreasing trend of Vp - see Christensen and Mooney (1995, p. 9779) and Kanao and Ishikawa (2004). This may explain the occurrence of low elastic velocities unusual at large depths.

The applied DRTG inversion determines the velocities for the horizontal directions. These velocities are increased if the encountered complexes have horizontal layering or foliation. Therefore, the macro-anisotropy effect should be considered whenever the foliation in the target bodies occurs. An example of significant anisotropy is well-documented at the rock complexes near the KTB super hole drilled at the western margin of the Bohemian Massif (Rabbel et al. 2004). The KTB borehole penetrated a metamorphic complex composed of paragneiss (70\%), amphibolite and metagabbro steeply dipping layers showing $7 \% \mathrm{Vp}$ anisotropy. When anisotropy was considered, a closer agreement between the DRTG model and the KTB log velocities was found (Novotný et al. 2009). For this sub-vertical foliation dominant in the metamorphic complex, the DRTG model correctly imaged the velocities decreased by $7 \%$ along the 'slowest' anisotropy axis trending across foliation (fig. $12 \mathrm{~d}$ in Novotný et al. 2009).

The grid cells used in the DRTG models are $5.0 \mathrm{~km}$ wide and $0.5 \mathrm{~km}$ high in accord with input data. However, the minimum lateral sizes of the targets yet distinguishable in velocity images are mostly $>5 \mathrm{~km}$ and depend on the strength of velocity anomalies. Therefore, in order to interpret the tomography results obtained, average rather than local petrophysical properties have to be considered. The average velocities, given by the travel times over a heterogeneous block, are similar but not the same due to the prevailing rock type inside. As well, the terms used to describe the structural elements in the velocity image cannot overcome this, rather regional, scope. For instance, interpreting the low- and high-velocity anomalies, the lithological terms as "felsic and mafic bodies" are used in the sense of the prevailing lithology of the interpreted 'large' blocks. Similarly, the geodynamic terms as "emplacements, sills, diapirs, gravity differentiation" used in connection with the sub-horizontal and sub-vertical velocity anomalies express the prevailing rather than exclusive dynamic processes responsible for their origin.

The travel-time response of an anomaly is proportional to its velocity excess and lateral size (ESM C). If it exaggerates the travel-time residuals after tomo- 
graphy imaging, the reliability of its performance could be statistically analyzed and expressed in the form of the depth-resolution curves for the final S04, S02 and S03 velocity models (Figs 9-11). The CEL09 velocity section (Fig. 12), involved in a common interpretation was derived by the same procedures including its lateral resolution - (fig. 14b in Novotný 2011). The geological backgrounds in Figs 9-12 correspond to the maps in Figs $2-3$. Underscores in the labels of encountered geological units mark their surface extents. The velocity structures revealed suggest sub-surface continuations of some faults (denoted by dashed lines). As discussed below, they are proposed to honor the trends of the mid-crustal subvertical anomalies.

\section{High-grade belts of the Moldanubian Zone}

The high-grade rocks occur in two SW-NE trending belts, eastern and western (Figs 1 and 3). The S03 and S02 sections (Figs 9-10) image the subsurface of these belts, partly covered by sediments of the Czech Cretaceous Basin (Fig. 1). In the Sudetic region, both profiles intersect almost perpendicularly the regional structures. The S03 section encounters here two major high-grade outcrops, the Orlica-Śnieżnik Dome (OSD) and the Góry Sowie Unit (GSU). Their HP and UHP rocks experienced the lower-crustal and upper-mantle conditions (Brückner et al. 1991; Kotková 2007; Jastrzębski et al. 2014). Dating of the (U)HP metamorphism yielded Early Carboniferous ages for the OSD (Chopin et al. 2012; Skrzypek et al. 2014) that were also detected further south, in the Gföhl Assembladge of the MLD (Hasalová et al. 2008). The high-grade rocks of the GSU within the FSB seem to have two different metamorphic-cooling histories (Kryza and Fanning 2007; Faryad and Kachlík 2013). West of the Sudetic Marginal Fault (SMF), the GSU experienced HPgranulite-facies conditions at $\sim 400 \mathrm{Ma}$ (O’Brien et al. 1997), and exhumation to mid-crustal levels at 380-370 Ma whereas east of the SMF, the metamorphic-exhumation history of the GSU is similar to that recorded in the OSD, i.e. the UHP metamorphism at $375 \mathrm{Ma}$ and subsequent exhumation at 345-330 Ma (Gordon et al. 2005).

\subsection{Eastern belt - felsic diapirs beneath the Orlica-Śnieżnik and Sowie Góry units}

The S03 profile follows the eastern belt of the HP rocks including, besides Moldanubian Zone, also the West Sudetes region (Fig. 3). Together with the parallel S02 profile, it intersects the major tectonic structures (Fig. 9): the Elbe Fault Zone (EFZ) and Odra Fault Zone (OFZ), the Intrasudetic Fault (ISF) and Sudetic Marginal Fault
(SMF) and images the mid-crustal HV elevations related with them. Figure 9 also suggests sub-surface continuation of their boundaries along the axes of velocity elevations (the dashed lines). Similarly, the boundaries of Fore Sudetic Monocline (FSM) and Dolsk Fault Zone (DFZ) correspond to the related $\mathrm{HV}$ elevations culminating at 6-8 km depths.

At the profile beginning, the S03 section encounters the Třebíč durbachite pluton (Fig. 2, km 10-32) imaged as a minor shallow, NE-dipping HV zone with slightly increased velocities of $6000-6050 \mathrm{~m} / \mathrm{s}$. Based on gravity modeling, Leichmann et al. (2016) inferred that the Třebíč Pluton reaches a thickness less than $2 \mathrm{~km}$. Further to the NNE, the S03 section images high-grade rocks of the Gföhl Assemblage within the EFZ. From $80 \mathrm{~km}$ onwards, they are covered by Cretaceous sediments (Fig. 3) reaching the thickness of 200-500 m.

At $120-150$ and $175-195 \mathrm{~km}$, the S03 section crosses two metamorphic complexes, the Orlica-Śnieżnik Dome (OSD) and Góry Sowie Unit (GSU). At the OSD position, the section shows three mid-crustal anomalies, a central LV diapiric body rimmed by two HV elevations. The HV elevations coincide with the northeast Elbe Zone boundary and Intra-Sudetic Fault (Fig. 9). A similar HV-LVHV triplet of alternating sub-vertical anomalies occurs beneath the Fore Sudetic Block (FSB) with the GSU cropping out at its SW margin (Fig. 3). At its enlarged upper part, the central LV diapiric anomaly ranges from 175 to $215 \mathrm{~km}$. Its enveloping HV elevations follow the neighboring Sudetic Marginal Fault and Odra Fault Zone.

Within the FSM, a minor mid-crustal LV block of $6050-6100 \mathrm{~m} / \mathrm{s}$ located at $263-274 \mathrm{~km}$ and $\sim 8 \mathrm{~km}$ depth is observed. Its position correlates with the phyllitic Bielawy-Trzebnica High (BTH) in the Variscan foreland (Fig. 3). The parallel $\mathrm{S} 02$ section also crosses the BTH $(\sim 50 \mathrm{~km} \mathrm{NWW}$ from the S03) and images its LV root in a deeper position of $\sim 10 \mathrm{~km}$ (Fig. 10). The BTH and paralleling Wolsztyn-Leszno High (WLH) resulted from a large-scale, N/NE folding under the lower greenschistsfacies conditions (Żelaźniewicz et al. 2003). The BTH anisotropic phyllites show the $\sim 6050 \mathrm{~m} / \mathrm{s}$ velocities in both $\mathrm{S} 02$ and $\mathrm{S} 03$ sections which indicates the minimum $\mathrm{Vp}$ values along the slowest axis of anisotropy across the layering.

The P-wave velocities of the S03 mid-crustal LV diapiric bodies range from 5800 to $6000 \mathrm{~m} / \mathrm{s}$. The same range of the $\mathrm{Vp}$ values also occurs in the $\mathrm{S} 02$ midcrustal LV diapirs (Fig. 10). Their composition can then correspond to the felsic gneiss with a higher content of silicates (see Section 6). The Vp contours in Figs 9-10 indicate that the $\mathrm{HV}-\mathrm{LV}-\mathrm{HV}$ anomalies continue beneath the imaged maximum depths. Since the central LV diapiric bodies clearly correlate with the western (Orlica) branch of the OSD and the GSU, the DRTG in Fig. 9 
obviously images the related high-grade OSD and GSU felsic gneiss intrusions.

At the beginning of the $\mathrm{S} 03$ section, a mid-crustal velocity depression is only marginally (not fully dotted) imaged near $85 \mathrm{~km}$ (Fig. 9). Its $6200-6300 \mathrm{~m} / \mathrm{s}$ isovelocities reached the $13-15 \mathrm{~km}$ depths. The depression is enveloped by two diapiric HV anomalies at $\mathrm{km} 70$ and 110 relating to the boundaries of EFZ; SSW boundary of EFZ at $60-70 \mathrm{~km}$ coincides here with the Železné hory Fault. Tentatively, the central velocity depression can be interpreted as a deep source of HP metamorphosed rocks of the Gföhl Assemblage that is partially covered by Cretaceous sediments (Figs 2-3). At the shallow levels, the velocities $c .6000-6050 \mathrm{~m} / \mathrm{s}$ are observed in a wide region (grey in Fig. 9) that may belong to the OSD root zone. The NNE-SSW trend of the OSD low-velocity anomaly supports the assumed affinity of the OSD to the Gföhl gneiss assemblage (Štípská et al. 2004).

\subsection{Western belt - felsic diapirs beneath the Gföhl and Ostrong assemblages}

The S02 line intersects the high-grade Moldanubian and Sudetic units (Fig. 3). In its SSW part, it images the subsurface of the western high-grade Moldanubian belt (ESM A1). The profile line parallels the Blanice Graben continuing south as the Kaplice and Rödl faults (Fig. 2). Two obliquely transverse, NW-SE trending faults, the Jáchymov Fault (JF) and eastern marginal Fault of the Třeboň Basin (FTB) are shown after Cháb et al. (2007) and Lenhardt et al. (2007). The FTB spans the area between the Blanice and Kaplice faults. The Blanice-Kaplice shear zone is part of the SSW-NNE trending regional fault system comprising further to the SE the Přibyslav-Vitis and Boskovice-Diendorf faults (Brandmayr et al. 1995; Žák et al. 2014). Within the Moldanubian s. s., the S02 section encounters the Ostrong (Monotonous Series) and Drosendorf (Variegated Series) assemblages located between two segments of the Gföhl Unit (Fig. 2). The HP-HT rocks of the Gföhl Assemblage are distributed in both western and eastern high-grade belts. Finger et al. (2007) assumed that they were exhumed along the TBU and Moravian boundaries. At 335-340 Ma, the Ostrong Assemblage adjacent to the Gföhl Assemblage underwent the LP-HT metamorphism caused by increased mantle heat flow after slab break-off (Janoušek and Holub 2007; Faryad et al. 2016).

\subsubsection{Upper-crustal HV bodies}

In its southern part, the S02 section images the Drosendorf and Ostrong assemblages between two segments of the Gföhl Assemblage (Fig. 10). The most conspicuous feature at $30-220 \mathrm{~km}$ along profile is a sub-horizontal HV anomaly (6000-6300 m/s) concordantly emplaced along the Blanice Graben beneath the EFZ, Gföhl and Ostrong assemblages. The $\mathrm{S} 04$ cross-view of this HV body is consistent in depths and velocities with the S02 image and reveals its width of $35 \mathrm{~km}$ (at the $6050 \mathrm{~m} / \mathrm{s}$ contour in Fig. 11). Post-emplacement tectonics apparently split this HV body into two segments at the FTB (Fig. 10). The gap between them occupies the Drosendorf Assemblage whose subsurface is practically gradient-free down to $\sim 9 \mathrm{~km}$. A deeply established velocity elevation beneath recorded a HV intrusion, the possible cause of the postemplacement tectonic movements.

The shorter HV southern segment (30-50 km) likely continues beyond the beginning of the $\mathrm{S} 02$ profile dipping SSW. The longer HV segment (70-220 km) plunges NNE to a depth of $6 \mathrm{~km}$ if the $6050 \mathrm{~m} / \mathrm{s}$ contour is considered. The S02 image reveals further details of its inner structure. At 120, 150 and $180 \mathrm{~km}$ along profile, three local velocity highs are observed, reaching more than 6300 $\mathrm{m} / \mathrm{s}$. Two are located beneath the Gföhl Assemblage and one within the Elbe Zone (Fig. 10). Their possible sources are obviously three mid-crustal HV elevations whose curved axes aim to the upper velocity maxima. These deep sources of the shallow mafic segment suggest its autochthonous nature - see further discussion in Section 9.1.

\subsubsection{Mid-crustal LV and HV anomalies}

The S02 mid-crustal anomalies strongly resemble those observed on the $\mathrm{S} 03$ section. They are again coupled to HV-LV-HV triplets: the S02 section images six pronounced HV narrow elevations $(\sim 7000 \mathrm{~km} / \mathrm{s})$ closely enveloping five $\mathrm{LV}$ cores with minimum $\mathrm{Vp}$ velocities under $6000 \mathrm{~m} / \mathrm{s}$ (Fig. 10). The LV diapiric cores correlate with the Ostrong and Gföhl assemblages, Elbe FZ, SKU, FSB, Odra FZ and BTH. Important features are that the HV elevations exhibit a high velocity gradient along their sub-vertical axes and, on the contrary, the intermediate diapiric LV anomalies are gradient-free with an almost constant $\sim 6000 \mathrm{~m} / \mathrm{s}$ velocity over a broad depth range from 20 to $8 \mathrm{~km}$. It indicates that the strong velocity and density gradients in the HV (mafic) bodies could result from the gravity differentiation at magmatic state, whereas the lighter LV (felsic) blocks always had a relatively homogeneous composition. Their probably higher rigidity prevented the mingling with the adjacent HV (mafic) melts during their ascent. Based on the above indications, the mid-crustal LV diapirs are interpreted to correspond to the felsic bodies, whose emplacement was driven mostly by buoyancy forces (Franěk et al. 2006, 2011a).

The deep LV root zones of the high-grade Ostrong and Gföhl assemblages are separated by a curved HV eleva- 
tion. Both mid-crustal LV roots are represented by two similar velocity depressions dipping SSW and reaching $\mathrm{Vp} \sim 6000 \mathrm{~m} / \mathrm{s}$ at the $14 \mathrm{~km}$ depth. Beneath the EFZ at $175 \mathrm{~km}$ along profile, another mid-crustal LV anomaly aims vertically down to $15 \mathrm{~km}$ depth, then dips NNE and obviously continues beneath $20 \mathrm{~km}$ depth. This pronounced LV zone can be traced outside the S02 section, as it will be discussed later.

At $228-240 \mathrm{~km}$ (Fig. 3), the S02 profile intersects the Krkonoše-Jizera Complex (KJC) in the South Krkonoše Unit (SKU) (e.g., Słaby and Martin 2008; Konopásek 2011). In the basement of the allochthonous SKU, the section images a narrow deep-seated LV diapir $(5900-6000 \mathrm{~m} / \mathrm{s})$ that is intercalated by two shallow intercalations with $\mathrm{Vp}$ increased to $6050-6100 \mathrm{~m} / \mathrm{s}$ (Fig. 10). A cusp of the $5900 \mathrm{~m} / \mathrm{s}$ contour may relate to the felsic intrusion here up to the $2 \mathrm{~km}$ depth. However, the above 5800 and $5700 \mathrm{~m} / \mathrm{s}$ cusps are shifted toward NNE and likely indicate the sub-horizontal tectonic movement assumed in this region (Mazur and Aleksandrowski 2001; Žáčková et al. 2010; Jeřábek et al. 2016). Further to NNE, the S02 section images the Variscan Internides buried beneath sediments of the deepening Carboniferous foreland basin. Two LV blocks underlie the OFZ and BTH at the depths of $8-11 \mathrm{~km}$. As it also imaged by the S03 section, both LV blocks have roots reaching deeper than $15 \mathrm{~km}$; the velocity depression under the BTH is only imaged on the parallel S03 section (Fig. 9). The LV roots are enveloped by pronounced HV elevations inclined to the NNE.

\subsubsection{Common mid-crustal roots of the Sudetic and Moldanubian felsic structures}

The S02 and S03 sections of the mid-crustal structures consistently show the common segmentation by the EFZ and OFZ and the paralleling Sudetic faults: the ISF, SMF and the faults at the southwestern margins of the MidGerman Crystalline High (MGCH) and Northern Phyllite Zone (NPZ) - see Figs 3, 9 and 10. These regional faults apparently correlate with the observed eight mid-crustal HV elevations whose axes then suggest their downward continuation. These axes also delineate the mafic magma ascents utilizing the weakness zones formed during the Variscan convergence (Aleksandrowski and Mazur 2002; Mazur et al. 2006). At present, the mid-crustal mafic bodies are imaged as the deep-seated HV elevations exhibiting a significant velocity gradient along their axes. The intermediate gradient-free LV sub-vertical anomalies inside each regional tectonic segment can be mostly identified as felsic intrusions.

To trace the felsic blocks outside the S03 and S02 sections, the gravity modeling by Chopin et al. (2012) was used. Along a density profile $\mathrm{CH} 1$ between the OSD and KJC (Fig. D1 in ESM D), the gravity model predicted an extensive $2.67 \mathrm{~g} / \mathrm{cm}^{3}$ low-density body covered by the Cretaceous sediments. The Bouguer anomaly map in Fig. D1 (top) shows a negative Bouguer anomaly due to the gneisses of the OSD that continues NW toward the KJC. Note that the shallow HV intercalation produces a local gravity high at the KJC and masks the effect of the light rocks ranging beneath at $6-16 \mathrm{~km}$ depths.

Another mid-crustal LV felsic root can be correlated within the EFZ. The S02 section at $175 \mathrm{~km}$ images it as a $\sim 15 \mathrm{~km}$ wide diapiric LV zone (Fig. 10). An overlying HV body reduces its negative gravity impact, which, however, still prevails. The gravity map (Fig. D1) presents the corresponding negative Bouguer anomaly that is broadening SE toward the S03 section. The S03 section follows a continuing gravity low due to the high-grade rocks in the eastern belt. This negative Bouguer anomaly probably corresponds to a buried felsic ridge extending along the EFZ axis. The ridge starts near the $\mathrm{S} 02$ section and widens toward the S03 line where it encompasses the OSD felsic root causing the most pronounced gravity low. The SSW branch of the OSD negative gravity anomaly supports the previous interpretation of the S03 velocity image: the deep OSD felsic root extends upward and continues SSW along the eastern Moldanubian highgrade belt.

The Kutná Hora Crystalline Unit (KHCU) thought by many authors to belong to the Gföhl Assemblage (Fig. 2) is well-expressed by Bouguer anomalies. The S02 and S04 sections encountered the KHCU at the $\sim 140$ or $\sim 213$ $\mathrm{km}$, respectively (Figs 10 and 11). Both profiles consistently image a mid-crustal LV body buried beneath a $\sim 5$ $\mathrm{km}$ thick HV body. However, the deeper felsic root of the KHCU produces a pronounced gravity low (Fig. D1).

\section{The transverse sections along S04 and CEL09 profiles}

The parallel S04 and CEL09 sections cross the Moldanubian high-grade belts in the NW-SE direction (Fig. 2). The Moldanubian s.s. distinctly differs in its regional gravity image from the surrounding Teplá-Barrandian Unit and Moravo-Silesian Zone. It exhibits an extensive gravity low reaching up to $-40 \mathrm{mGal}$ at both $\mathrm{S} 04$ and CEL09 sections. Guy et al. (2011) built a regional 3-D density model comprising the light felsic rocks in the Moldanubian domain down to $20-35 \mathrm{~km}$. The felsic lower crust is assumed to be the SXT slab subducted here from NW. Janoušek et al. (2004), Franěk (2011a) and Guy et al. (2011) proposed this felsic lower crust to be the possible source of the HP-UHP rocks of the Gföhl Assemblage. 
The CEL09 section revealed the subduction features due to the SXT slab underthrusting the TBU and Central Bohemian Shear Zone (CBSZ) - see Novotný $(2011,2012)$ for details. Figure 12 presents the SE part of the SXT slab detachment surface plunging beneath the CBSZ and Central Bohemian Plutonic Complex (CBPC). Three regional fault systems intersect the highgrade Moldanubian belts, the Blanice-Kaplice-Rödl, Přibyslav-Vitis and Boskovice-Diendorf fault zones (Fig. 2). According to the S04 and CEL09 velocity images (Figs 11-12), the downward continuation of these regional faults seems to be related to the mid-crustal velocity depressions.

The previous CEL09 and S04 models, inferred by Hrubcová et al. $(2005,2010)$ and Růžek et al. (2007), comprise the lower crust and upper mantle. These models differently imaged the Blanice Graben (BG) intersecting the profiles near the No 44070 and 29100 shot points, respectively. The forward modeling, applied by Hrubcová et al. $(2005,2010)$ did not image any crustal velocity depression except a pronounced Moho minimum occurring at the CEL09 section. At the BG, both the Rüžek et al. (2007)'s models show a crust-scale velocity depression deepened to $\sim 35 \mathrm{~km}$. The DRTG models of the uppermost $20 \mathrm{~km}$ Moldanubian crust achieved the resolution suitable for studying the exhumation signatures.

\subsection{The shallow HV emplacements}

Between the Blanice and Boskovice faults, the S04 and CEL09 profiles map the subsurface of the Drosendorf and Gföhl assemblages, as well as Moravian nappes (Fig. 2). The S04 velocity section passes the NE margin of the Drosendorf Assemblage that is located between the two outcrops of the Gföhl Assemblage (Fig. 11). The CEL09 profile comprises short ranges of the Drosendorf and Ostrong assemblages, then passes the SBB adjacent to the Prribyslav-Vitis Fault and finally images the subsurface of the Gföhl and Moravo-Silesian units (Fig. 12).

The S04 and S02 sections commonly show a HV body beneath the high-grade Gföhl Assemblage. The P-wave velocities reaching $6200-6300 \mathrm{~m} / \mathrm{s}$ indicate its mafic composition. Along the $\mathrm{S} 02$ section (Fig. 10), this HV body dips from 4 to $7 \mathrm{~km}$ depth as outlined by the 6050 $\mathrm{m} / \mathrm{s}$ contour. The $\mathrm{S} 04$ profile provides its transverse width of $35 \mathrm{~km}$ that corresponds to the extent of the KHCU (Kachlík 1999; Štědrá and Nahodilová 2009; Nahodilová et al. 2011). The KHCU crops out on the NW flank of the Drosendorf Terrane as a part of the Gföhl Assemblage (Figs 2 and 11).

Another thicker HV body, imaged by the S04 and CEL09 sections, is located beneath the Gföhl Assemblage at the SE flank of the Drosendorf Assemblage in the eastern high-grade belt (Figs 11 and 12). With the $6300 \mathrm{~m} / \mathrm{s}$ maxima located at the depth of 6 and $8 \mathrm{~km}$, respectively, both the sections record its minimal depth of $1 \mathrm{~km}$ at the $6000 \mathrm{~m} / \mathrm{s}$ isovelocity. The HV body fades out toward the Prribyslav-Vitis Fault System (PVFS), i.e., within the low-grade Drosendorf Assemblage at the S04 section. On the contrary, the Ostrong and Gföhl assemblages always exhibit $\mathrm{HV}$ emplacements on a regional scale (Figs 2, 10-12).

\subsection{Mid-crustal anomalies}

An extensive mid-crustal LV anomaly appears across the Moldanubian sector. It is more pronounced (lower than $5700 \mathrm{~m} / \mathrm{s}$ ) in the S04 than CEL09 sections where it reaches $\sim 5900 \mathrm{~m} / \mathrm{s}$ (Figs 11-12). However, the depression reaches the same depth of $\sim 12 \mathrm{~km}$ by the $6000 \mathrm{~m} / \mathrm{s}$ contour in both sections. The mid-crustal LV anomaly at the S04 section seems to be split to three velocity depressions localized beneath three segments of the Gföhl, Drosendorf and again Gföhl assemblages - see also Fig. 10 for the transverse S02 velocity image. These deeply rooted depressions probably represent their felsic root zones. Three associated velocity minima at $\sim 9.5 \mathrm{~km}$ depth obviously developed after a later HV intercalation at $220 \mathrm{~km}$ (Fig. 11). At shallow depths, this intercalation forms up two HV sills underlying both segments of the Gföhl Assemblage with a gap beneath the lower-grade Drosendorf Assemblage. Interpretation of the sub-vertical extrusions of felsic masses is also supported by the presence of accompanying deep-seated $\mathrm{HV}$ intrusions located near the inter-terrane boundaries at 220 and $275 \mathrm{~km}$ along profile.

One hundred kilometers to the south-west, the CEL09 section still images a mid-crustal LV anomaly centered around the PVFS. Its extent is reduced at shallow depths by two HV promontories beneath the South Bohemian Batholith and Gföhl Assemblage (Fig. 12). The HV intrusion in the SE promontory underlies the Gföhl Assemblage, similarly as in all other profile sections. The deeply seated LV anomaly can be again considered as a felsic root zone of the high-grade Gföhl Assemblage. It means more probable interpretation than that given previously (Novotný 2012, p. 263).

Between the S04 and CEL09 profiles, the S02 section images two mid-crustal LV anomalies surrounded by three deeply established HV elevations. Since these LV anomalies are beneath the Ostrong and Gföhl assemblages (Fig. 10), they are interpreted as their felsic root zones. Note that the shallow HV sill has three major mafic sources imaged as mid-crustal HV elevations (Section 6.2.1). The middle one is also imaged in the S04 section at the Gföhl-Drosendorf assemblage boundary (Fig. 11). 


\section{Discussion on the origin of HV bodies emplaced at shallow depths}

\subsection{Sudetic and Moldanubian regions}

All sections show extensive HV anomalies at shallow depths within the high-grade terrains. They are interpreted as mafic intrusions intersecting felsic sub-vertical diapirs. The most conspicuous, $150 \mathrm{~km}$ long, HV body is emplaced above four felsic diapirs occurring along the TBU-MLD boundary (Fig. 10). As a probable source of this mafic intrusion, the $\mathrm{S} 02$ section suggests three midcrustal HV elevations whose curved axes aim to three local velocity highs (greater than $6300 \mathrm{~m} / \mathrm{s}$ ) inside the shallow HV anomaly - see the arrows in Fig. 10. Their positions correlate with positive aeromagnetic highs $\Delta \mathrm{T}$ near the profile line (fig. 2.1.5 in Novotný et al. 2004). The dashed arrows in Fig. 10 may represent the conduits of the mafic melts across the overlying LV layer. Their widths are surely beyond the lateral resolution achieved in the velocity image: according to Fig. 7, the resolvable widths reach $7-18 \mathrm{~km}$ for the $68 \%$ confidence and 300 $\mathrm{m} / \mathrm{s}$ velocity excess. An analogous, shallowly emplaced, HV layer, variable in its thickness and velocities, is also imaged by the S03 section (Fig. 9) beneath the OSD, GSU and BTH.

The felsic diapirs observed in the velocity sections are always coupled with mafic intrusions, which intercalate them at shallow levels. Note that there are many felsic outcrops in the high-grade terrains exhibiting mafic envelopes such as the Mafic Boundary Complex (MBC) in Lardeaux et al. (2014). The MBC, originally called 'Begleit Series' also occurs at the boundary of the Gföhl and Drosendorf assemblages (e.g., Fuchs 1976; Racek et al. 2006). It often rims the granulite bodies in the Moldanubian Zone (Tajčmanová et al. 2010; Franěk et al. 2011b; Lexa et al. 2011) or Saxothuringian and Vosgian high-grade terrains (Franke 2000; Schulmann et al. 2002).

\subsection{Saxothuringian Zone}

At its beginning, the S04 profile passes the Saxonian Granulite Massif (SGM) - Fig. 1. More structural information was provided by the previous seismic projects, DEKORP 3/MVE 90 and GRANU 1995 (Behr et al. 1994; Enderle et al. 1998). A striking feature revealed by the reflection and refraction profiles is an extensive HV layer underlying the SGM that continues SW beneath the whole Saxothuringian Zone (fig. 5 in DEKORP and Orogenic Processes Research Groups 1999). The HV layer has a $\sim 4 \mathrm{~km}$ thickness and P-wave velocities between 6.0 and $6.4 \mathrm{~km} / \mathrm{s}$, which the DRTG also confirmed at the S04 section (Novotný et al. 2010, fig. 5).
Behr (1978) and Weber and Behr (1983) described the exhumation of the SGM by a diapiric folding model; during the crustal shortening, the granulitic layer was deformed and pierced weaker middle crust. This type of exhumation as vertical extrusions was also suggested for the Moldanubian granulites (Štípská et al. 2004; Schulmann et al. 2005; Franěk et al. 2006). Lexa et al. (2011) proposed that the granulite domes surrounded by middle crustal rocks are a result of the Viséan gravity redistribution.

\section{Discussion on the tomography and thermo-mechanical modeling results}

\subsection{Featuring the diapiric felsic intrusions}

The velocity patterns of the UHP-HP metamorphosed felsic rocks exhumed in the eastern Bohemian Massif, pertain to the final stages of their ascent originated in the upper mantle and lower crust. The refraction tomography at mid-crustal levels particularly showed that:

1) the ascending felsic rocks split into multiple sub-vertical LV bodies (sheets) following the transverse NW-SW Variscan faults,

2) the felsic LV diapirs always have HV mafic envelopes,

3 ) the HV elevations, imaging the accompanying mafic envelopes, always show strong velocity gradients along their sub-vertical axes,

4) just one HV elevation is usually observed between neighboring felsic diapirs (cores).

The single mafic envelope should not be then simulated by the fold-dominated models producing doubled mafic flanks on high-grade rock cores. The only exception from (4) is the double-headed HV elevation observed between the ISF and SMF (Fig. 9). In this case, the adjacent felsic diapirs seem to belong to two different exhumation events (Section 6).

Note that Štípská et al. (2011) suggested large-scale folds to explain the juxtaposition of eclogite and midcrustal rocks in the eastern (Śnieżnik) branch of the OSD gneiss which lies outside the $\mathrm{S} 03$ section.

\subsection{A scenario for triggering the multiple felsic ascents}

For the Moldanubian Zone, Finger et al. (2007) and Janoušek and Holub (2007) proposed slab break-off as a heat source. Lexa et al. (2011) suggested thermal incubation of 10-15 Myr to heat and convert the underplated felsic layer into granulites via dehydration melting. Gerya et al. (2004) estimated the density changes in the subducted crust under granulite-facies conditions. Assuming its felsic to intermediate composition, they estimated a 
density decrease by $50-150 \mathrm{~kg} / \mathrm{m}^{3}$. Therefore, in early exhumation phases, such a density decrease may trigger the buoyancy-driven ascents of the felsic material subducted to mantle depths. Under steady collision conditions empowering diapiric intrusion, the high-grade crustal rocks would start to ascend inside less viscous and denser magmas. The following scenario leading to the multiple ascents of felsic diapirs can be proposed:

1) A slab of felsic crustal rocks reaches mantle-depth conditions stimulating its initial melting,

2) Mafic melts intrude inside and across the felsic slab. They contribute to slab break-off and separate several felsic blocks at the same depth level,

3) Heating up the felsic blocks causes phase transitions leading to a considerable decrease of rock density,

4) Buoyancy forces trigger uplift of individual felsic blocks encircled by (yet lighter) mafic melts in a viscous denser medium. The buoyant complexes form diapiric shapes piercing preferably the weakened crust zones,

5) In collision regime, the more liquid-like mafic envelopes would likely precede the ascending felsic cores and form the upper sills observed.

Such a scenario produces a group of high-grade felsic diapiric domes enveloped by mafic rocks, including the upper sills, observed by the DRTG.

Hacker and Liou (1998) debated to which extent the world-known UHP terrains could coherently develop in situ. Their possible allochthonous origin could be indicated by 'common outcrop occurrence of eclogite pods with sheared borders enclosed in gneiss or marble'. The parallel multiple diapirs, observed in the $\mathrm{S} 02$ and $\mathrm{S} 03$ sections, rather confirm that the exhumed complexes were coherently produced in situ. As to a time scale, Gerya et al. (2002) studied exhumation processes in viscous medium driven by the Rayleigh-Taylor gravity instabilities caused by a buoyant felsic layer. They deduced that the gravitational redistribution in the form of crustal diapirism might occur within 10-100 Myr. This period may be substantially reduced for a buoyant uplift within a weak tectonic zone.

\subsection{Thermo-mechanical models}

The DRTG provided evidence for the coupled mafic and felsic intrusive bodies ascending through upper 15 or $20 \mathrm{~km}$ of the crust. The results obtained could partially constrain the numerical simulations of thermal and mechanical conditions at these and deeper levels where subduction of a felsic slab turns to its exhumation observed on a regional scale.

Alternating HV and LV sub-vertical anomalies, like those imaged by the S02 and S03 sections, commonly appear beneath high-grade terrains. Gerya and Burg (2007) modeled the finger-shaped HV intrusions as a thermal structure. These authors argued that 'similar thermal structures should be a widespread feature associated with partially molten mantle diapirs (cold plumes) generated in the proximity of subducting slabs.' Burov et al. (2014) reviewed the history of thermo-mechanical modeling of continental subduction and exhumation of HP and UHP rocks. The continental subduction and exhumation modeled as transient processes usually last 5-10 Myr. Subduction of crustal rocks is increasingly accepted as a common scenario inherent to the convergence of continental plates and micro-continents.

Schubert et al. (2013) simulated injection of hot mafic magma into a partially molten lower-crustal zone. The induced overpressure triggers the development of brittle/ plastic shear zones and ascent of felsic magmas into upper crustal levels. The authors considered heat supply by mafic underplating to be a widespread process at diverse geological settings. Although the results of simulations (see fig. 2 in Schubert et al. 2013) produced features differing from those observed in the West Sudetes, otherwise specified constraints on the buoyancy-triggered ascents could yield more realistic results.

\subsubsection{Models of the Moldanubian crust colliding with the Brunia microplate}

Duretz et al. (2011) performed the first analog and numerical experiments to test the conceptual models of continental indentation suggested by Schulmann et al. (2005, 2008) for the eastern Bohemian Massif. They simulated the indentation-induced exhumation and extrusion of the lower Moldanubian crustal nappe over a rigid indenter.

Maierová et al. (2014) carried out extensive numeric modeling of various tectonic scenarios of crustal deformation at the contact between the eastern Moldanubian and Moravo-Silesian zones. They left apart the mantlecrust interaction and modeled deformation of crustal layers with contrasting viscosities. The authors presented some reasons for such separate modeling based on a microstructural study of peridotites and granulites occurring in the region (Kusbach et al. 2012, 2015) and the fact that no ultramafic compositions were found in the cores of the crustal antiforms (Franěk et al. 2011a; Chopin et al. 2012). The 2-D modeling involved a collision of two crustal blocks comprising three and two layers. The three-layer block had inverse layering: a mafic layer (middle crust) was placed above the felsic, less rigid layer (Moldanubian lower crust). The adjacent two-layer block (Brunia micro-continent) had a normal layering. Three basic parameters were varied: the velocity of model-domain shortening due to the Brunia indentation, the rate of erosion and radiogenic heat production within the felsic lower crust. Although the heat and mass 
interchanges between the crust and mantle were not considered, the resulting models yielded realistic styles of crustal deformation. The simulations especially produced diapirism-like and fold-dominated deformations. The pressure-temperature-time $(\mathrm{P}-\mathrm{T}-\mathrm{t})$ paths of the ascended felsic lower crust also approached the available data.

\subsubsection{Constraints following from tomography results}

The 2-D collision models obtained by Maierová et al. (2014) simulated many subduction and exhumation properties observed in both the high-grade belts of the Moldanubian crust. However, comparing them with the structural patterns revealed by the DRTG, some features are contradictory or yet unconsidered:

1) A missing feature is velocity/density differentiation in all mafic envelopes accompanying the felsic diapiric bodies. To simulate the relatively homogeneous felsic masses ascending with their mafic envelopes, the thermo-mechanical collision models should involve locally increased advective heat fluxes occurring in (mantle-derived) mafic magmas.

2) Another missing feature is the occurrence of a common mafic layer penetrating the felsic intrusions; instead, the modeled fold-dominated deformations produced rather individualized mafic caps.

3) Modeling should aim to simulate multiple diapiric felsic bodies produced by Rayleigh-Taylor instabilities. Until now, the modeled folding style of deformed layers has yielded the doubled mafic flanks between neighboring felsic diapirs. However, no doubled envelopes of felsic cores have been imaged by the DRTG. In conclusion, the tomography evidence supports those geodynamic models that are based on the deep mass extrusions rather than diapiric folding. As summarized in the scenario in Section 10.2, the observed diapir-like ascents of multiple felsic blocks suggest their origin due to break-off of a subducted felsic slab. Their subsequent exhumation is driven by buoyancy forces. The concurrently ascending hotter mafic magmas were likely the main heat supplier. They enhanced exhumation of felsic cores as their less viscous envelopes. As well, under steady collision regime, the more liquid-like mafic envelopes likely preceded their ascending felsic cores and formed the observed upper sills.

\section{Concluding remarks}

The improved resolution and mutual consistency of the velocity sections obtained were the basis for the presented geological interpretation. The de-blurred DRTG images provided clear correlations of the mid-crustal dia- piric LV anomalies with the high-grade complexes of the OSD and GSU, both prevailingly formed by exhumed (U) HP felsic rocks. The collateral S02 and S03 sections then revealed that the expected sub-vertical mass transfer is related to the major WNW-ESE trending Sudetic faults. The mid-crustal LV anomalies beneath the high-grade Ostrong and Gföhl assemblages were identified as their felsic root zones. They were consistently imaged by the S02, S04 and CEL09 profiles including an extensive HV body shallowly emplaced alongside the Blanice Graben.

The exhumation processes associated with the highgrade terrains of the eastern Bohemian Massif and West Sudetes are always characterized by HV sills at shallow depths. On a wider scale, an extensive HV layer was also recorded beneath the Saxonian Granulite Massif and whole Saxothuringian Zone. The occurrence of HV bodies, detected in all velocity sections beneath the highgrade Moldanubian Zone arises a question whether their higher grade metamorphism could not have been caused by the interaction with the emplaced mafic magmas.

The presented DRTG results can contribute to a better understanding of the crustal architecture of the Variscan orogenic root. The features deduced from velocity sections, i.e., the multiple felsic gradient-free diapiric cores enveloped by mafic intrusions with strong velocity gradients and finally, occurrence of flat mafic sill-like bodies at shallow depths are assumed to be the key pattern of felsic diapirism associated with continental collision anywhere else.

Acknowledgments. This study was supported by the Institute of Geophysics, Academy of Sciences of the Czech Republic. The SUDETES 2003 data on the Czech territory were acquired via the broad international cooperation and SUDETES 2003 Working Group. Financial support was provided by the research project No 630/3/02 funded by Ministry of Environment of the Czech Republic. The author is indebted to the handling editor Alexandra Guy, chief editor V. Janoušek and reviewers S. Mazur and J. Valenta for their suggestions and devoted comments provided during the manuscript preparation.

Electronic supplementary material (ESM). Additional information for this paper is available online at the Journal web site (http://dx.doi.org/10.3190/jgeosci.270). The ESM $A$ briefly describes the Moldanubian high-grade units and the used tomographic method, ESM B contains the refraction data and their pre-processing, ESM $C$ documents lateral resolution achieved in the derived velocity sections and compares them with the previous results, ESM D summarizes the gravity support of the velocity sections relevant for their interpretation. The figures, tables and equations in ESM $A-D$ are numbered independently of each other with prefixes A-D. 


\section{References}

Aleksandrowski P, Mazur S (2002) Collage tectonics in the north-easternmost part of the Variscan Belt: the Sudetes, Bohemian Massif. In: Winchester JA, PHARAOH TC, Verniers J (eds) Palaeozoic Amalgamation of Central Europe. Geological Society, London, Special Publications 201: 237-277

BEHR H (1978) Subfluenz-Prozesse im Grundgebirgs-Stockwerk Mitteleuropas. Z Dtsch geol Gesell 129: 283-318

Behr HJ, DEKORP Research Group B (1994) Crustal structure of the Saxothuringian Zone: results of the deep seismic profile MVE-90 (East). Z geol Wiss 22: 647-769

Brandmayr M, Dallmeyer RD, Handler R, WallBRECHER E (1995) Conjugate shear zones in the southern Bohemian Massif (Austria) - implications for Variscan and Alpine tectonothermal activity. Tectonophysics 248 : 97-116

Brownlee SJ, Hacker BR, Salisbury M, Seward G, Little TA, BAldwin SL, Abers GA (2011) Predicted velocity and density structure of the exhuming Papua New Guinea ultrahigh-pressure terrane. J Geophys Res 116: B08206

BrüCKNer HK, Medaris LG JR, BaKun-Czubarow N (1991) $\mathrm{Nd}$ and $\mathrm{Sr}$ age and isotope patterns from Variscan eclogites of the eastern Bohemian Massif. Neu Jb Mineral, Abh 163: 169-196

Burov E, Francois T, Agarda P, Le Pourhiet L, Meyer B, Tirel C, Lebedev S, Yamatod P, Brun JP (2014) Rheological and geodynamic controls on the mechanisms of subduction and HP/UHP exhumation of crustal rocks during continental collision: insights from numerical models. Tectonophysics 631: 212-250

Cháb J, Stráník Z, Eliáš M, AdAmovič J, BABŮrek J, Breiter K, CAJZ V, DomeČKa K, FiŠERA M, HANŽL P, Holub V, Hradecký P, Chlupáč I, Klomínský J, Mašek J, Mlčoch B, Opletal M, Otava J, Pálenský P, Prouza V, RŮŽIČKa M, SCHOVÁNEK P, SLABÝ J, VALEČKA J, ŽÁČEK V (2007) Geological map of Czech Republic 1:500 000 (uncovered). Czech Geological Survey, Prague

Chopin F, Schulmann K, Skrzypek E, Lehmann J, DuJardin JR, Martelat JE, LeXa O, Corsini M, Edel JB, ŠTíPSKÁ P, PITRA P (2012) Crustal influx, indentation, ductile thinning and gravity redistribution in a continental wedge: building a Moldanubian mantled gneiss dome with underthrust Saxothuringian material (European Variscan belt). Tectonics 31, doi:10.1029/2011TC002951

Christensen NI, Mooney WD (1995) Seismic velocity structure and composition of the continental crust: a global view. J Geophys Res 100: 9761-9788

Claerbout JF (1971) Toward a unified theory of reflector mapping. Geophysics 36: 467-481

DEKORP and Orogenic Processes Research Groups (1999) Structure of the Saxonian granulites: geological and geophysical constraints on the exhumation of highpressure/high-temperature rocks in the mid-European Variscan belt. Tectonics 18: 756-773

Duretz T, Kaus BJP, Schulmann K, Gapais D, KermarREC JJ (2011) Indentation as an extrusion mechanism of lower crustal rocks: insight from analogue and numerical modelling, application to the eastern Bohemian Massif. Lithos 124: 158-168

Edel JB, Weber K (1995) Cadomian terranes, wrench faulting and thrusting in the central Europe Variscides: geophysical and geological evidence. Geol Rundsch 84: 412-432

Enderle U, Schuster K, Prodehl C, Schulze A, Bribach J (1998) The refraction seismic experiment GRANU95 in the Saxothuringian belt, SE-Germany. Geophys J Int 133: 245-259

FARYAD SW, KACHLÍK V (2013) New evidence of blueschist facies rocks and their geotectonic implication for Variscan suture(s) in the Bohemian Massif. J Metamorph Geol 31: 63-82

FARYAD SW, KaChlík V, Sláma J, JedličKa R (2016) Coincidence of gabbro and granulite formation and their implication for Variscan HT metamorphism in the Moldanubian Zone (Bohemian Massif), example from the Kutná Hora Complex. Lithos 264: 56-69

FedIuK F (2005) The Lower Vltava River Pluton: a semihidden intrusive complex in Neoproterozoic at the northern outskirts of Prague, Central Bohemia. J Czech Geol Soc 50: 71-78

Finger F, Gerdes A, JANOUŠEK V, René M, Riegler G (2007) Resolving the Variscan evolution of the Moldanubian sector of the Bohemian Massif: the significance of the Bavarian and the Moravo-Moldanubian tectonometamorphic phases. J Geosci 52: 9-28

FraněK J, Schulmann K, LeXa O (2006) Kinematic and rheological model of exhumation of high pressure granulites in the Variscan orogenic root: example of the Blanský les granulite, Bohemian Massif, Czech Republic. Mineral Petrol 86: 253-276

FraněK J, Schulmann K, Lexa O, Tomek Č, Edel JB (2011a) Model of syn-convergent extrusion of orogenic lower crust in the core of the Variscan Belt: implications for exhumation of high-pressure rocks in large hot orogens. J Metamorph Geol 29: 53-78

FraněK J, Schulmann K, Lexa O, Ulrich S, Haloda J, TÝCOVÁ P (2011b) Origin of felsic granulite microstructure by heterogeneous decomposition of alkali feldspar and extreme weakening of orogenic lower crust during the Variscan Orogeny. J Metamorph Geol 29: $103-130$

FrANKE W (2000) The mid-European segment of the Variscides: tectonostratigraphic units, terrane boundaries and plate tectonic evolution. In: Franke W, HaAK V, Oncken O, Tanner D (eds) Orogenic Processes: Quan- 
tification and Modelling in the Variscan Belt. Geological Society, London, Special Publications 179: 35-61

Franke W, ŻelaźniewicZ A (2000) The eastern termination of the Variscides: terrane correlation and kinematic evolution. In: Franke W, HaAk V, Oncken O, TANNER D (eds) Orogenic Processes: Quantification and Modelling in the Variscan Belt. Geological Society, London, Special Publications 179: 63-86

Fuchs G (1976) Zur Entwicklung der Böhmischen Masse. Jb Geol B-A 129: 41-49

Geissler WH, Kämpf H, Skácelová Z, Plomerová J, BABUŠKA V, KIND R (2012) Lithosphere structure of the NE Bohemian Massif (Sudetes) - a teleseismic receiver function study. Tectonophysics 564-565: 12-37

GERYA TV, BURG JP (2007) Intrusion of ultramafic magmatic bodies into the continental crust: numerical simulation. Phys Earth Planet Inter 160: 124-142

Gerya TV, Perchuk LL, Maresch WV, Willner AP, Van REENEN DD, SMIt CA (2002) Thermal regime and gravitational instability of multi-layered continental crust: implications for the buoyant exhumation of high-grade metamorphic rocks. Eur J Mineral 14: 687-699

Gerya TV, PerchuK LL, Maresch WV, WiLlner AP (2004) Inherent gravitational instability of hot continental crust: implications for doming and diapirism in granulite facies terrains. In: WhitNey DL, TeysSiER CH, SidDoway CHS (eds) Gneiss Domes in Orogeny. Geological Society of America Special Papers 380: pp 97-116

Gordon SM, Schneider DA, MANeCKi M, Holm DK (2005) Exhumation and metamorphism of an ultrahighgrade terrane: geochronometric investigations of the $\mathrm{Su}-$ detes Mountains (Bohemia), Poland and Czech Republic. J Geol Soc, London 162: 841-855

Grad M, ŠpičÁK A, Keller GR, Guterch A, Brož M, BRÜCKL E, HEGEDÜs E (2003) SUDETES 2003 seismic experiment. Stud Geophys Geod 47: 681-689

Grad M, Guterch A, Mazur S, Keller GR, Špičćk A, HRUbCoví P, GeISSLER WH (2008) Lithospheric structure of the Bohemian Massif and adjacent Variscan Belt in central Europe based on profile S01 from the SUDETES 2003 experiment. J Geophys Res 113: B10304

Guterch A, Grad M, ŠpičÁK A, Brückl E, Hegedüs E, Keller GR, Thybo H (2003a) An overview of recent seismic refraction experiments in central Europe. Stud Geophys Geod 47: 651-657

Guterch A, Grad M, Keller GR, Posgay K, Vozár J, ŠpičÁk A, Brückl E, Hajnal Z, Thybo H, Selvi O, CELEBRATION 2000 Seismic Experiment Team (2003b) CELEBRATION 2000 Seismic Experiment. Stud Geophys Geod 47: 659-670

Guy A, Edel JB, Schulmann K, Tomek Č, Lexa O (2011) A geophysical model of the Variscan orogenic root (Bohemian Massif): implications for modern collisional orogens. Lithos 124: 144-157
HACKer BR, Liou JG (eds) (1998) When Continents Collide: Geodynamics and Geochemistry of UltrahighPressure Rocks. Kluwer, Dordrecht, pp 1-325

HACKER BR, KeLEMEN PB, BeHN MD (2011) Differentiation of the continental crust by relamination. Earth Planet Sci Lett 307: 501-516

Harjes HP, Bram K, Durbaum H, Gebrande H, Hirschmann G, Janik M, Thomas R, Tormann J, WenZEL F (1997) Origin and nature of crustal reflections: results from the integrated seismic measurements at the KTB super-deep drilling site. J Geophys Res 102(B8): $18267-18288$

HASALOVÁ P, JANOUŠEK V, SCHULMANN K, ŠTíPSKÁ P, ERBAN V (2008) From orthogneiss to migmatite: geochemical assessment of the melt infiltration model in the Gföhl Unit (Moldanubian Zone, Bohemian Massif). Lithos 102: 508-537

Hrubcová P, Środa P, ŠpičÁK A, Guterch A, Grad M, Keller GR, Brueckl E, Thybo H (2005) Crustal and uppermost mantle structure of the Bohemian Massif based on CELEBRATION 2000. J Geophys Res 110: B11305

Hrubcová P, Środa P, Grad M, Geissler WH, Guterch A, VozÁr J, Hegedüs E, Sudetes 2003 Working Group (2010) From the Variscan to the Alpine Orogeny: crustal structure of the Bohemian Massif and the Western Carpathians in the light of the SUDETES 2003 seismic data. Geophys J Int 183: 611-633

JANOUŠEK V, HoLUB F (2007) The causal link between HP/ HT metamorphism and ultrapotassic magmatism in collisional orogens: case study from the Moldanubian Zone of the Bohemian Massif. Proc Geol Assoc 118: 75-86

JaNoušEK V, Bowes DR, Rogers G, FARrow CM, JeLÍNEK E (2000) Modelling diverse processes in the petrogenesis of a composite batholith: the Central Bohemian Pluton, Central European Hercynides. J Petrol 41: 511-543

JaNOUŠEK V, Finger F, Roberts MP, FrÝDA J, PIN C, DOLeJš D (2004) Deciphering the petrogenesis of deeply buried granites: whole-rock geochemical constraints on the origin of largely undepleted felsic granulites from the Moldanubian Zone of the Bohemian Massif. Trans Roy Soc Edinb, Earth Sci 95: 141-159

JastrZĘBSKi M, StawikowsKi W, BudzyŃ B, OrŁowskie R (2014) Migmatization and large-scale folding in the Orlica-Śnieżnik Dome, NE Bohemian Massif: pressuretemperature-time-deformation constraints on Variscan Terrane assembly. Tectonophysics 630: 54-74

JeŘÁBEK, P, KonopáSEK J, ŽÁĆKovÁ E (2016) Two-stage exhumation of subducted Saxothuringian continental crust records underplating in the subduction channel and collisional forced folding (Krkonoše-Jizera Mts., Bohemian Massif). J Struct Geol 89: 214-229

KАCHLÍK V (1999) Relationship between Moldanubicum, the Kutná Hora Crystalline Unit and Bohemicum (Central 
Bohemia, Czech Republic): a result of the polyphase Variscan nappe tectonics. J Czech Geol Soc 44: 201-291

KANAO M, ISHIKAWA M (2004) Origins of the lower crustal reflectivity in the Lützow-Holm Complex, Enderby Land, East Antarctica. Earth Planets Space 56: 151-162

KonopáseK J (2011) Tectonic position of eclogites and blueschists in the Bohemian Massif. Geolines 23: 11-17

KonopáseK J, Schulmann K (2005) Contrasting Early Carboniferous field geotherms: evidence for accretion of a thickened orogenic root and subducted Saxothuringian crust (Central European Variscides). J Geol Soc, London 162: 463-470

Koткоv'́ J (2007) High-pressure granulites of the Bohemian Massif: recent advances and open questions. J Geosci 52: 45-71

KryZa R, FAnNing CM (2007) Devonian deep-crustal processes and uplift in the Variscan Orogen: evidence from SHRIMP zircon ages from the HT-HP granulites and migmatites of the Góry Sowie (Polish Sudetes). Geodin Acta 20: 159-175

Kusbach V, Ulrich S, Schulmann K (2012) Ductile deformation and rheology of subcontinental mantle in a hot collisional orogeny: example from the Bohemian Massif. J Geodyn 56-57: 108-123

Kusbach V, Janoušek V, Hasalová P, Schulmann K, FANNING CM, ERban V, Ulrich S (2015) Importance of crustal relamination in origin of the orogenic mantle peridotite-high-pressure granulite association: example from the Náměšt' Granulite Massif (Bohemian Massif, Czech Republic). J Geol Soc, London 172: 479-490

Lardeaux JM, Schulmann K, Faure M, Janoušek V, LeXa O, Skrzypek E, Edel JB, ŠTíPská P (2014) The Moldanubian Zone in the French Massif Central, Vosges/ Schwarzwald and Bohemian Massif revisited: differences and similarities. In: Schulmann K, Martínez CataláN JR, Lardeaux JM, JanoušeK V, Oggiano G (eds) The Variscan Orogeny: Extent, Timescale and the Formation of the European Crust. Geological Society, London, Special Publications 405: 7-44

Leichmann J, Gnojek I, Novák M, Sedlák J, Houzar S (2016) Durbachites from the Eastern Moldanubicum (Bohemian Massif): erosional relics of large, flat tabular intrusions of ultrapotassic melts - geophysical and petrological record. Int J Earth Sci (Geol Rundsch) 106: 59-77

Lenhardt WA, Švancara J, Melichar P, Pazdírková J, Havír J, SÝKoroví Z (2007) Seismic activity of the Alpine-Carpathian-Bohemian Massif region with regard to geological and potential field data. Geol Carpath 4 : 397-412

Lexa O, Schulmann K, Janoušek V, Štípská P, Guy A, RACEK M (2011) Heat sources and trigger mechanisms of exhumation of HP granulites in Variscan orogenic root. J Metamorph Geol 29: 79-102
Maierová P, Lexa O, Schulmann K, ŠtíPská P (2014) Contrasting tectono-metamorphic evolution of orogenic lower crust in the Bohemian Massif: a numerical model. Gondwana Res 25: 509-521

Majdanski M, Grad M, Guterch A, SUDETES 2003 WorkING Group (2006) 2-D seismic tomographic and ray tracing modelling of the crustal structure across the Sudetes Mountains basing on SUDETES 2003 experiment data. Tectonophysics 413: 249-269

MaJdANSKi M, KoZlovsKaYa E, GRAD M, SUDETES 2003 WorkING Group (2007) 3D structure of the Earth's crust beneath the northern part of the Bohemian Massif. Tectonophysics 437: 17-36

Matte P, Maluski H, Rajlich P, Franke W (1990) Terrane boundaries in the Bohemian Massif: result of large-scale Variscan shearing. Tectonophysics 177: 151-170

Mazur S, Aleksandrowski P (2001) The Teplá-Saxothuringian suture in the Karkonosze-Izera Massif, Western Sudetes, Central European Variscides. Int J Earth Sci 90: 341-360

Mazur S, Aleksandrowski P, Kryza R, Oberc-Dziedzic T (2006) The Variscan Orogen in Poland. Geol Q 50: $89-118$

Nahodilová R, Faryad SW, Dolejš D, Tropper P, KONZETT J (2011) High-pressure partial melting and melt loss in felsic granulites in the Kutná Hora Complex, Bohemian Massif (Czech Republic). Lithos 125: 641-658

NovotnÝ M (1981) Two methods of solving the linearized two-dimensional inverse seismic kinematic problem. J Geophys 50: 7-15

NovotnÝ M (2011) Depth-recursive tomography of Bohemian Massif at CEL09 transect - part A: deblurrring of velocity image and resolution estimates. Surv Geophys 32: $827-855$

Novotný M (2012) Depth-recursive tomography of the Bohemian Massif at the CEL09 transect - part B: interpretation. Surv Geophys 33: 243-273

Novotný M (2013) Refraction Tomography of the Bohemian Massif structures: a critical review and reply to the comments of Hrubcová et al. Surv Geophys 34: 531-540

NovotnÝ M, Brož M, HrubCová P, KAROUSOVÁ O, ŠPiČÁK A, Švancara J, ALP Working Group, SUDETES WorkING Group (2004) SLICE - Seismic Lithospheric Investigation of Central Europe. Technical report, Czech Geological Survey-Geofond, Prague (in Czech)

NovotnÝ M, Skácelová Z, Mrlina J, MLČoch B, RŮŽek B (2009) Depth-recursive tomography along the Eger Rift using the S01 profile refraction data: tested at the KTB super drilling hole, structural interpretation supported by magnetic, gravity and petrophysical data. Surv Geophys 30: $561-600$

Novotný M, SkÁcelová Z, MlČoch B (2010) Crustal structures beneath the Saxonian Granulite Massif, the 
České Středohoří and the Doupovské Hory Mts. based on the depth-recursive tomography. J Geosci 55: 81-94 O'BrIEN PJ, KRÖNER A, JAECKel P, HeGNER P, ŹELAŻNIEWICZ A, KryZa R (1997) Petrological and isotopic studies on Palaeozoic high-pressure granulites, Góry Sowie Mts., Polish Sudetes. J Petrol 38: 433-456

Pitra P, Burg JP, Guiraud M (1999) Late Variscan strike-slip tectonics between the Teplá-Barrandian and Moldanubian terranes (Czech Bohemian Massif): petrostructural evidence. J Geol Soc, London 156: 1003-1020

Rabbel W, Beilecke T, Bohlen T, Fischer D, Frank A, Hasenclever J, Borm G, Kück J, Bram K, Druivenga G, Lüschen E, Gebrande H, Pujol J, Smithison S (2004) Superdeep vertical seismic profiling at the KTB deep drill hole (Germany): seismic close-up view of a major thrust zone down to $8.5 \mathrm{~km}$ depth. J Geophys Res 109: B09309

Racek M, Ští́pská P, Pitra P, Schulmann K, Lexa O (2006) Metamorphic record of burial and exhumation of orogenic lower and middle crust: a new tectonothermal model for the Drosendorf Window (Bohemian Massif, Austria). Mineral Petrol 86: 221-251

RUDNICK RL, FountaIN DM (1995) Nature and composition of the continental crust: a lower crustal perspective. Rev Geophys 33: 267-309

RUDNICK RL, GAO S (2003) Composition of the continental crust. In: Holland HD, TUREKIAN KK, RUDNick RL (eds) The Crust. Treatise on Geochemistry 3. ElsevierPergamon, Oxford, pp 1-64

RŮŽEK B, HrubCová P, NovotnÝ M, ŠPiČÁK A, Karousová O (2007) Inversion of travel times obtained during active seismic refraction experiments CELEBRATION 2000, ALP 2002 and SUDETES 2003. Stud Geophys Geod 51: $141-164$

Scheck M, Bayer U, Otto V, Lamarche J, Banka D, Pharaoh T (2002) The Elbe Fault System in North Central Europe - a basement-controlled zone of crustal weakness. Tectonophysics 360: 281-299

Schubert M, Driesner T, Gerya TV, Ulmer P (2013) Mafic injection as a trigger for felsic magmatism: a numerical study. Geochem Geophys Geosyst 14: doi: 10.1002/ ggge. 20124

Schulmann K, Schaltegger U, JežEK J, Thompson AB, EDEL JB (2002) Rapid burial and exhumation during orogeny: thickening and synconvergent exhumation of thermally weakened and thinned crust (Variscan Orogen in Western Europe). Amer J Sci 302: 856-879

Schulmann K, Kröner A, Hegner E, Wendt L, KoNOPÁSEK J, LEXA O, ŠTíPSKÁ P (2005) Chronological constraints on the pre-orogenic history, burial and exhumation of deep-seated rocks along the eastern margin of the Variscan Orogen, Bohemian Massif, Czech Republic. Amer J Sci 305: 407-448
Schulmann K, Lexa O, Štípská P, Racek M, TajČmanová L, Konopásek J, Edel JB, Peschler A, LeHMANN J (2008) Vertical extrusion and horizontal channel flow of orogenic lower crust: key exhumation mechanisms in large hot orogens? J Metamorph Geol 26: $273-297$

Schulmann K, Konopásek J, Janoušek V, Lexa O, LARDEAUX JM, EDEL JB, ŠTíPSKÁ P UlRICH S (2009) An Andean type Palaeozoic convergence in the Bohemian Massif. C R Geosci 341: 266-286

Schulmann K, Lexa O, Janoušek V, Lardeaux JM, Edel JB (2014) Anatomy of a diffuse cryptic suture zone: an example from the Bohemian Massif, European Variscides. Geology 42: 275-278

Skáceloví Z, MlČoch B, Mrlina J, NovotnÝ M (2011) Upper crustal structure of the northern part of the Bohemian Massif in relation to geological, potential field data and new deep seismic data (Eger/Ohře Rift, Central Europe). Z geol Wiss 1: 1-18

SŁaby E, Martin H (2008) Mafic and felsic magma interaction in granites: the Hercynian Karkonosze Pluton (Sudetes, Bohemian Massif). J Petrol 2: 353-391

SKRZYPek E, LehManN J, SZCZEPAŃSKi J, ANCZKiewicz R, ŠTíPSKÁ P, SCHUlMANN K, KRÖNER A, BiAŁEK D (2014) Time-scale of deformation and intertectonic phases revealed by $\mathrm{P}-\mathrm{T}-\mathrm{D}-\mathrm{t}$ relationships in the orogenic middle crust of the Orlica-Śnieżnik Dome, Polish/Czech Central Sudetes. J Metamorph Geol 32: 981-1003

ŠTĚDRÁ V, NAHODILOVÁ R (2009) High-pressure metabasic rocks from the Kutná Hora Complex: geological position and petrology of exotic lithologies along the segmented Moldanubian margin, Bohemian Massif. J Geosci 54: 135-157

ŠTíPSKÁ P, SChUlManN K, KRÖNER A (2004) Vertical extrusion and middle crustal spreading of omphacite granulite: a model of syn-convergent exhumation (Bohemian Massif, Czech Republic). J Metamorph Geol 22: 179-198

ŠTípská P, Chopin F, Skrzypek E, Schulmann K, Pitra P, Lexa O, Martelat JE, Bollinger C, Ž́́ćčová E (2011) The juxtaposition of eclogite and mid-crustal rocks in the Orlica-Śnieżnik Dome, Bohemian Massif. J Metamorph Geol 30: 213-234

TAJČMANOvá L, SOEJono I, KonopáseK J, KoŠLER J, KLÖTZLI U (2010) Structural position of high-pressure felsic to intermediate granulites from NE Moldanubian domain (Bohemian Massif). J Geol Soc, London 167: 329-345

WeBER K, BeHR HJ (1983) Geodynamic interpretation of the Mid-European Variscides. In: MARTin H, EdER FW (eds) Intracontinental Fold Belts. Case studies in the Variscan Belt of Europe and the Damara Belt in Namibia. Springer, Berlin, pp 427-469

ŻelaźNIEWICZ A, MarheIne D, Oberc-DZiedZic T (2003) A Late Tournaisian synmetamorphic folding and thrust- 
ing event in the eastern Variscan foreland: ${ }^{40} \mathrm{Ar} /{ }^{39} \mathrm{Ar}$ evidence from the phyllites of the Wolsztyn-Leszno High, western Poland. Int J Earth Sci 92: 185-194

ŽáčKová E, KonopáseK J, JeřÁbeK P, Finger F, KošLer J (2010) Early Carboniferous blueschist facies metamorphism in metapelites of the West Sudetes (northern Saxothuringian Domain, Bohemian Massif), J Metamorph Geol 28: 361-379

ŽÁ́ J, Holub FV, Verner K (2005) Tectonic evolution of a continental magmatic arc from transpression in the upper crust to exhumation of mid-crustal orogenic root recorded by episodically emplaced plutons: the Central Bohemian Plutonic Complex (Bohemian Massif). Int J Earth Sci (Geol Rundsch ) 94: 385-400
Žák J, Kratinová Z, Trubač J, Janoušek V, Sláma J, MrLina J (2011) Structure, emplacement, and tectonic setting of Late Devonian granitoid plutons in the TepláBarrandian unit, Bohemian Massif. Int J Earth Sci (Geol Rundsch ) 100: 1477-1495

Žák J, Verner K, Janoušek V, Holub FV, Kachlík V, Finger F, Hajná J, Tomek F, Vondrovic L, Trubač J (2014) A plate-kinematic model for the assembly of the Bohemian Massif constrained by structural relationships around granitoid plutons. In: SCHULMANN K, MarTíneZ Catalán JR, Lardeaux JM, Janoušek V, Oggiano G (eds) The Variscan Orogeny: Extent, Time Scale and the Formation of the European Crust. Geological Society, London, Special Publications 405: 169-196 